\title{
Practical Mitigation Strategies for Countering the Spread of Aerosolized COVID-19 Virus (SARS-CoV-2) Using Ventilation and HEPA Air Purifiers: A Literature Review
}

\author{
Panayiotis Polyzois, Shirley Thompson \\ Department of Natural Resource Management, University of Manitoba, Winnipeg, Canada \\ Email: polyzoip@myumanitoba.ca
}

How to cite this paper: Polyzois, P., \& Thompson, S. (2021). Practical Mitigation Strategies for Countering the Spread of Aerosolized COVID-19 Virus (SARS-CoV-2) Using Ventilation and HEPA Air Purifiers: A Literature Review. Journal of Geoscience and Environment Protection, 9, 166-197. https://doi.org/10.4236/gep.2021.99010

Received: August 12, 2021

Accepted: September 26, 2021

Published: September 29, 2021

Copyright $\odot 2021$ by author(s) and Scientific Research Publishing Inc. This work is licensed under the Creative Commons Attribution International License (CC BY 4.0).

http://creativecommons.org/licenses/by/4.0/ (c) (i) Open Access

\begin{abstract}
This paper assesses, through an extensive literature review, the use of ventilation and High-Efficiency Particulate Air (HEPA) purifiers as practical mitigation strategies for reducing the spread of aerosolized COVID- $19^{1}$ virus. HEPA is a well-defined standard by the U.S. Department of Energy for filters. The focus of the literature review was on indoor air quality (IAQ) and COVID-19, with a particular emphasis on classroom settings. The start of the review, January 2020, was chosen to coincide with the first cases of COVID-19 in North America. Although children under the age of 12 are currently not yet vaccinated, there is mounting pressure for a return to normal by the start of the new school year, 2021. Also, many classrooms lack pre-installed mechanical ventilation systems (Olsiewski et al., 2021); therefore, mitigation in classrooms often falls solely in the hands of teachers and students. Research shows that ventilation and air purification are essential tools to counter aerosolized transmission $(<5 \mu \mathrm{m})$ of the COVID-19 virus. According to Curtius et al., (2020), the inhaled dose of particles containing virus RNA is six times lower when using air purifiers with an $\mathrm{ACH}$ (air changes per hour) of 5.7. However, ventilation and air purifiers are not replacements for masks, which remain vital for countering droplet $(>5 \mu \mathrm{m})$ transmission. In addition, occupancy (i.e., number and proximity of people present in a given area) and group activity levels (e.g., talking, shouting, singing) play a critical role in viral transmission. Although natural ventilation by opening windows can be an essential strategy to help counter the spread of the virus, the level of ventilation offered by opening windows is largely uncontrollable as it is subject to weather
\end{abstract}

${ }^{1}$ COVID-19 refers to the disease which is developed once sufficient viral transmission occurs. The virus itself which causes COVID-19 is labeled as "severe acute respiratory syndrome Coronavirus 2," otherwise known as SARS-CoV-2, and sometimes called the "COVID-19 virus" (WHO, 2020b). 
conditions and building design. One must also consider the energy implications (i.e., loss of heat) that this strategy carries. Scientific evidence shows that varying levels of continuous and/or intermittent ventilation, either mechanical or natural, combined with the use of HEPA air purifiers, can provide a higher degree of protection than window access alone (Curtius et al., 2020). Systematic deployment of a hybrid mitigation strategy incorporating both ventilation and HEPA air purification in schools, offices, or other facilities offers a practical way to establish a safe re-opening of society in Canada.

\section{Keywords}

COVID-19, SAS-CoV-2, Aerosolized, Ventilation, HEPA Air Purifier(s)

\section{Highlights}

- Ventilation practices are critical for mitigating the transmission of aerosolized COVID-19 virus.

- Natural ventilation (opening windows) is a viable strategy to mitigate virus aerosols but depends on building design and weather conditions.

- HEPA air purifiers offer additional protection against aerosolized transmission $(<5 \mu \mathrm{m})$ of the COVID-19 virus.

- Ventilation alone does not offer significant protection against droplet transmission $(>5 \mu \mathrm{m})$ of the COVID-19 virus and is, therefore, not an alternative to mask use.

\section{Introduction}

Severe acute respiratory syndrome coronavirus 2 (SARS-CoV-2), otherwise known as the COVID-19 virus (WHO, 2020b), is what causes the coronavirus-19 disease (COVID-19). The objective of this literature review is to analyze practical mitigation strategies to help prevent the aerosolized transmission of the COVID-19 virus indoors, with a particular emphasis on classroom settings. The development of government-issued guidelines was inconsistent during the first year of the pandemic, due to conflicting statements issued by various health and government organizations. The main point of contention during this time involved the dominant mode of transmission. Whether the COVID-19 virus is spread primarily through larger respiratory droplets or smaller respiratory aerosols has important implications for prevention.

To set the context, we begin with a brief timeline of events surrounding the now widespread acceptance of the risk associated with aerosolized COVID-19 virus. More specifically, the paper examines how the public can use ventilation practices and High-Efficiency Particulate Air (HEPA) air purifiers to prevent viral spread in a pragmatic sense. First, we evaluate the risks associated with 
aerosolized $(<5 \mu \mathrm{m})$ transmission of the COVID-19 virus, as well as evaluate different aerosolized mitigation scenarios. Second, we frame these different scenarios and their associated risks according to the overall transmission risk posed by the virus. From this analysis, we make several recommendations regarding the use of natural ventilation and HEPA air purifiers as primary lines of defence against the spread of the COVID-19 virus. The recent surge of several new, more highly contagious and transmittable strains of SARS-CoV-2, originating from the U.K., South Africa, Brazil, and India, makes this intervention even more critical (CBC, 2021).

\subsection{The Development of Guidelines for Preventing the COVID-19 Virus: A Timeline}

Early in the pandemic, the many controversies and uncertainties surrounding the risk associated with airborne transmission resulted in inconsistent directives on how to prevent the spread of the COVID-19 virus. For the purpose of setting the context, in this section, we briefly discuss the early confusion surrounding viral transmission through the air and how this confusion limited the widespread adoption of effective prevention measures.

Airborne transmission of the COVID-19 virus indoors was well-accepted by scientists (Morawska \& Cao, 2020; Morawska \& Milton, 2020; Flanagan, 2020) since the early stages of the pandemic. However, the World Health Organization (WHO) was silent on COVID-19's airborne transmission until July 9, 2020 (World Health Organization, WHO, 2020a). Three days earlier, on July 6, 2020, Morawska and Milton (2020) published a statement supported by 239 scientists, expressing grave concern about the lack of recognition of the risk associated with airborne transmission of the COVID-19 virus and the absence of a clear recommendation to counter its spread. In response, the WHO (2020a) agreed that the COVID-19 virus is transmitted by both respiratory droplets, classified as particles having a diameter greater than $5 \mu \mathrm{m}$, and respiratory aerosols, classified as particles having a diameter equal to or smaller than $5 \mu \mathrm{m}$.

Other sources, such as the Centres for Disease Control and Prevention (CDC), also did not provide clear directives on how to protect against COVID-19 transmission. From the beginning of the pandemic, the CDC reported that the virus spreads primarily through large droplets (Elfrink et al., 2020). Later, the CDC added: “... small particles, such as those in aerosols, were a common vector" (Elfrink et al., 2020: p. 1). However, this statement was retracted four days later with the following admission, "The Friday [September 17, 2020] update was posted in error ... [and the $\mathrm{CDC}$ ] is returning to its earlier version [that the virus mostly spreads through large droplets] ..." (Elfrink et al., 2020: p. 1). Nevertheless, the CDC finally reversed its position and agreed that aerosol transmission of the COVID-19 virus is a real threat (CDC, 2020c).

Even after the CDC and the WHO recognized COVID-19 respiratory aerosol transmission, Canada did not do so until November 2020 (Flanagan, 2020). 
However, prior to official recognition of the risk, Canada's health officials warned against residing in poorly ventilated areas to curb transmission risk. Dr. Tellier, a Canadian infectious diseases specialist and medical microbiologist, asserted that the warning by Canada's health officials is an inadvertent recognition of the risk associated with aerosolized spread (Miller, 2020a). In urging recognition of aerosolized health risk, Dr. Tellier explained: "From a practical point of view, it's very inconvenient to acknowledge aerosol transmission because it takes a lot more work to deal with it" (Kirkey, 2020). Despite this, the aerosol transmission risk for COVID-19 eventually warranted a significant shift in both the Canadian and American governments' public health recommendations (Miller, 2020a; Jee, 2020).

\subsection{Respiratory Droplets and Aerosols}

Respiratory droplets (particles $>5 \mu \mathrm{m}$ in diameter) and respiratory aerosols (particles $<5 \mu \mathrm{m}$ in diameter) are created through sneezes, coughs, talking, and even normal breathing. Respiratory droplets fall quickly to the ground within minutes ( $\mathrm{Li}$ et al., 2021), and ventilation systems do not effectively alter their spread (Miller, 2020b). Respiratory aerosols carrying viruses like COVID-19, can stay airborne for up to three hours, allowing long-distance travel (WHO, 2020a; van Doremalen et al., 2020). The duration of time that an aerosol remains suspended in the air depends on the aerosol particle size, the relative humidity, and the indoor air changes per hour (ACH) (Morawska, 2006; Kohanski et al., 2020).

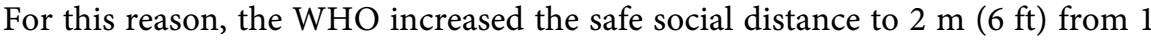
$\mathrm{m}(3 \mathrm{ft})$. However, several accredited studies argue that an even greater distance than $2 \mathrm{~m}$ is needed for protection (Mittal et al., 2020; Bahl et al., 2020; Bourouiba, 2020; Li \& Qian, 2020). Mittal et al. (2020) found that respiratory droplets can travel as far as $8 \mathrm{~m}$ under certain circumstances.

Although respiratory droplet transmission is understood to dominate the spread of the COVID-19 virus, the risk due to aerosolized transmission is less certain (Jayaweera et al., 2020). Potentially, aerosols may pose a higher risk for COVID-19 than droplets. One such example is the widespread transmission of the COVID-19 virus on the Diamond Princess Cruise ship during its February 2020 voyage, with the ship's inadequate ventilation system as a contributing factor (Stephans, 2020; Hung et al., 2020). Under strict quarantine practices, 711 out of 3711 (19\%) of the passengers were infected with COVID-19, and 14 people died.

The level of ventilation in an indoor space directly impacts the transmission risk associated with respiratory aerosols. Increased ventilation helps reduce aerosolized transmission risk. Poor ventilation, especially in overcrowded spaces, increases the potential for aerosol transmission (Li \& Qian, 2020). Occupancy, the measure of how crowded a space is, also plays a direct role in the risk of viral transmission. Occupancy not only impacts one's ability to remain socially distanced but also increases the likelihood that an infected individual is present. To 
prevent the spread of COVID-19, the public is urged to avoid unventilated indoor spaces altogether when social distance cannot be maintained (von Seidlein et al., 2021). If this is not possible, the Government of Canada (2021c) recommends the use of air purifiers without providing any further guidance. Currently, the utility of air purifiers alone to reduce the spread of the COVID-19 virus in unventilated, or poorly ventilated, high-occupancy spaces is under scientific debate. However, scientific evidence shows that when used in combination with proper ventilation, HEPA air purifiers can effectively mitigate the aerosolized COVID-19 virus (Public Health Ontario, 2020a, 2020b; Curtius et al., 2020; Mousavi et al., 2020).

Avoiding unventilated spaces is impossible for many workers and residents. While the pandemic hit the general population very hard, minority groups, who often work as frontline workers, and Indigenous people, who often live in overcrowded housing, face even higher risks (Thompson et al., 2020). According to Sze et al. (2020), ethnic minority groups are disproportionately affected by the novel COVID-19. The housing shortage in First Nation reserves in Canada has Indigenous people living in overcrowded and poorly ventilated homes (Government of Canada, 2015). As a result, a large number of native people in Canada are affected by underlying respiratory illnesses (Nwanaji-Enwerem et al., 2020) and other chronic diseases (Thompson et al., 2020), including higher rates of COVID-19 infections (3.3 times that of the general public) (Government of Canada, 2021d).

\section{Method}

An extensive literature review was undertaken to identify research on various practical mitigation strategies used to prevent the aerosolized spread of the COVID-19 virus focusing on ventilation and HEPA air purification. The literature reviewed included academic journals, professional and government-sponsored reports, as well as best practice guidelines published between January 2020 and January 2021. Both American and Canadian Government policies and regulations regarding IAQ and COVID-19 were examined.

Academic, peer-reviewed literature on COVID-19 is limited due to the virus being a recent development. A list of articles was obtained through the University of Manitoba's library search engine (with access to 649 different databases, including Scopus, Web of Science, PubMed, and ScienceDirect) using the primary keywords: COVID-19, Coronavirus, and SARS-CoV-2 and the supplementary keywords: ventilation, HEPA, air purifier, window, and indoor air quality. HEPA is a well-defined standard by the U.S. Department of Energy for filters that can remove at least $99.97 \%$ of airborne particles with a size of at least $0.3 \mu \mathrm{m}$.

The results from the University of Manitoba's library search, listed in Table 1, show that the majority of the papers address the effects of ventilation, with only a few that focus on air purifiers or indoor air quality related to COVID-19. 
Table 1. Number of articles related to COVID-19, Coronavirus, and SARS-CoV-2 paired with different supplementary terms relating to ventilation and purification between January 1,2020 , and January 28, 2021, using the University of Manitoba's library search engine.

\begin{tabular}{|c|c|c|c|c|}
\hline \multirow[t]{2}{*}{ Article Types } & \multirow[t]{2}{*}{$\begin{array}{c}\text { Primary Search Words } \\
\text { in the Review of the Literature } \\
\text { (January } 1,2020 \text {, to January } 28,2021 \text { ) }\end{array}$} & \multicolumn{3}{|c|}{$\begin{array}{c}\text { Combination Search Words in } \\
\text { the Review of the Literature } \\
\text { (January } 1,2020 \text {, to January } 28,2021 \text { ) }\end{array}$} \\
\hline & & COVID-19 & Coronavirus & SARS-CoV-2 \\
\hline \multirow{5}{*}{ All Media } & + "Ventilation" & 467 & 75 & 39 \\
\hline & + “HEPA" & 9 & 3 & 1 \\
\hline & + "Purifier" & 5 & 8 & 3 \\
\hline & + "Window" & 58 & 30 & 9 \\
\hline & + "Indoor Air Quality" & 14 & 3 & 5 \\
\hline \multirow{5}{*}{ Journal Articles } & + "Ventilation" & 116 & 9 & 10 \\
\hline & + "HEPA" & 0 & 0 & 0 \\
\hline & + "Purifier" & 1 & 0 & 0 \\
\hline & + "Window" & 11 & 0 & 4 \\
\hline & + "Indoor Air Quality" & 5 & 0 & 2 \\
\hline
\end{tabular}

*These numbers are not mutually exclusive, as several articles include more than one search word.

Article titles, then abstracts, were initially analyzed for key information relevant to the topic of research in this study: COVID-19 virus aerosol transmission and practical measures for its mitigation. Article choices were further narrowed to those with a focus on practical ventilation and HEPA air purification strategies. Additional supplementary material discovered with Google Search Engine and Google Scholar, including news stories and government documents, were also examined and, where applicable, incorporated into the literature review for historical context. The material was read for relevant content without any other content analysis. In total, 47 journal articles, 2 conference papers, 35 reports, and 13 news articles were ultimately incorporated into this paper.

\section{Findings}

The findings of this literature review cover the following key areas: the aerosolized spread of the COVID-19 virus, including the synergistic effect between particulate matter (e.g., wood smoke) and viruses; practical mitigation strategies for countering the spread of aerosolized COVID-19, which include ventilation (both mechanical and natural) and HEPA air purification with special attention given to the case for HEPA purifiers in schools; and finally, the risk of virus transmission associated with different human activities (e.g., breathing, speaking, shouting, and singing), particularly in indoor environments.

\subsection{Aerosolized Spread of the COVID-19 Virus}

As of the publication date of this article, the Canadian government has no stan- 
dardized ventilation or air purification protocols for mitigating aerosols to prevent the spread of the COVID-19 virus indoors (Government of Canada, 2021c). In January 2021, 360 experts concerned with the lack of official action to counter the spread of aerosolized COVID-19 virus sent an open letter to Canada's Chief Public Health Officer, politicians, and medical officials across Canada (The Canadian Press, 2021). A prominent concern was the COVID-19 virus transmission in areas with inadequate indoor ventilation. The risk of aerosolized virus transmission is significantly higher indoors than outdoors (CDC, 2020b). This risk is even higher with inadequate ventilation practices and in restricted spaces where social distancing is not an option (CDC, 2020a).

As shown in Figure 1, respiratory aerosols are emitted at a proportionally greater rate with higher volumes of spoken vocalization (Alsved et al., 2020). Loud singing, which involves higher sound pressure, deeper breaths, and higher peak airflows, emit even more aerosols. Even with the use of a facemask, loud singing can generate more fine aerosols $(<2 \mu \mathrm{m})$ than normal talking without a mask (Alsved et al., 2020). The increased rate of breathing from exercise activity also results in a rising aerosol emission rate. Vigorous activity produces higher breathing rates which, in turn, result in both higher inhalation and expulsion rates. According to Mittal et al. (2020), the combined effect from these breathing rates can significantly increase transmission risk in indoor spaces $100-1000$ times during medium-to-heavy workouts compared to normal breathing activity. Figure 1 shows the wide range of larger and smaller particle counts based on different human activities.

\section{Particulate Matter in the Spread of COVID-19}

Poor indoor air quality (IAQ) negatively impacts respiratory health and can create even higher risks related to COVID-19 (Nwanaji-Enwerem et al., 2020). Indoor air quality is directly related to the size, distribution, and concentration of airborne particles, such as non-exhaust particles (road traffic), cooking aerosol, wood smoke, and cigarette smoke (Harrison, 2020; Tran et al., 2021). Particle size is especially significant as it directly impacts penetration potential. Small particles, less than $10 \mu \mathrm{m}$ (PM10) in diameter, pose the most significant health problem due to their ability to reach the lungs and bloodstream (Environmental Protection Agency, 2021a). Of concern to health officials is the tendency of different airborne particles to work in synergy, creating an even greater health risk. For example, radon and particulate matter (PM), such as cigarette smoke, work hand-in-hand to increase the chances of developing lung cancer (National Research Council, 1999).

COVID-19 viral aerosols with a diameter of $0.1-0.2 \mu \mathrm{m}$ remain airborne longer by interacting with airborne particulate matter (Comunian et al., 2020; Setti et al., 2020; Barakat et al., 2020). Such interaction increases the susceptibility to COVID-19 and may contribute to higher mortality rates (Tung et al., 2021; Comunian et al., 2020; Wu et al., 2020). This synergistic effect between particulate matter and viruses is of specific concern for communities where woodstoves 


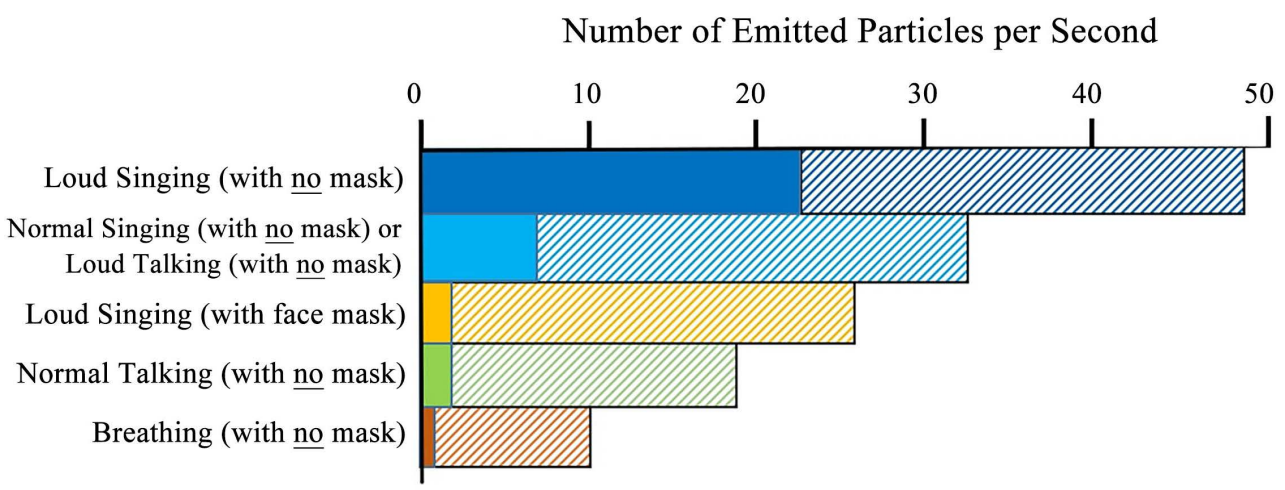

Legend:

Solid Colours: Particles $>2 \mathrm{~mm}$

W/, Hatched Colours: Particles $\leq 2 \mathrm{~mm}$

Figure 1. Number of emitted particles per second as a function of particle size during various activities, based on data from Alsved et al. (2020).

are common. Biomass combustion through the use of woodstoves can result in high indoor harmful particulate concentrations if the woodstoves are not adequately maintained or vented (Semmens et al., 2015). Additionally, creosote can build up along chimney walls, causing a significant fire hazard and reduced airflow, resulting in significantly higher particulate concentration indoors (Environmental Protection Agency, 2021b; Polyzois, 2019).

\subsection{Mitigating the Aerosolized Spread of the COVID-19 Virus}

Two methods for mitigating particulate matter concentrations and respiratory aerosols are ventilation and HEPA air purifiers. In the absence of either ventilation or purification of the indoor air, particulate matter concentrations can remain airborne for hours (van Doremalen et al., 2020). Polyzois (2019), who tested the distribution of wood smoke particles (PM2.5) in a closed room, showed that such particles can remain airborne even after 12 hours.

\subsubsection{Ventilation}

Currently, ventilation is the most common strategy being employed to counter the spread of aerosolized COVID-19. The ventilation rate for indoor space is measured in air changes per hour ( $\mathrm{ACH}$ ), defined as the number of times the air in a room is completely changed or renewed with clean air in a single hour. Kohanski et al. (2020) define aerosols as particles having a diameter of $0.1-10 \mu \mathrm{m}$ and droplets as particles having a diameter of $5-100 \mu \mathrm{m}$. Table 2 shows the suspension time of aerosols and droplets in an indoor environment under various values of $\mathrm{ACH}$. The airborne suspension of particles depends on particle size.

A mechanical ventilation system is typically required to clear the infected space from any virus-laden particles that are still airborne. Such a system with an $\mathrm{ACH} \geq 1$ can clear the room of suspended aerosols that tend to be airborne 
for more than $1 \mathrm{~h}$. This level of $\mathrm{ACH}$ is not adequate to clear airborne droplets. A mechanical ventilation system with an $\mathrm{ACH} \geq 10$ can clear the room of suspended aerosols and droplets that tend to be airborne for more than $6 \mathrm{~min}$.

The American Society of Heating, Refrigerating and Air-Conditioning Engineers (ASHRAE, 2021) recommends an ACH rate of at least six to abate the aerosolized spread of COVID-19 in school classrooms. Both hospitals and airplanes maintain environments with high air exchange rates, which are ideal for countering the aerosolized spread of the COVID-19 virus. ACH for different environments in industry are shown in Table 3. Commercial airlines typically have a higher total air change rate than hospital operating rooms because of their higher occupancy, which requires higher air change rates.

Table 2. Duration of time that particles of various sizes remain suspended in the air depending on the Indoor Air Changes per Hour (ACH) (Kohanski et al., 2020).

\begin{tabular}{ccc}
\hline \multirow{2}{*}{$\begin{array}{c}\text { Indoor Air Change } \\
\text { per Hour }(\mathrm{ACH})\end{array}$} & Terosols & Time that Particles Remain Suspended in the Air Before Settling at a 1-m Distance \\
\cline { 2 - 3 } $\mathrm{ACH}=0$ & $6 \mathrm{~min}-13$ days & $3 \mathrm{sec}-19 \mathrm{~min}$ \\
$\mathrm{ACH} \geq 1$ & $6 \mathrm{~min}-1$ hour & $3 \mathrm{sec}-19 \mathrm{~min}$ \\
$\mathrm{ACH} \geq 10$ & $3 \mathrm{sec}-6 \mathrm{~min}$ & $3 \mathrm{sec}-6 \mathrm{~min}$ \\
\hline
\end{tabular}

${ }^{\star}$ Aerosols are defined by Kohanski et al. (2020) as particles having a diameter of $0.1 \mu \mathrm{m}-10 \mu \mathrm{m}$. ${ }^{*}$ Droplets are defined by Kohanski et al. (2020) as particles having a diameter of $5 \mu \mathrm{m}-100 \mu \mathrm{m}$.

Table 3. Air-changes-per-hour (ACH) rates commonly found in different environments in industry (Boeing, 2013; CMTA, 2020; ASHRAE, 2021; Aviation Public Health Initiative, 2020).

\begin{tabular}{|c|c|c|c|c|c|c|c|}
\hline \multirow{6}{*}{$\begin{array}{l}\text { Source of } \\
\text { Fresh Air }\end{array}$} & \multicolumn{7}{|c|}{ Environment } \\
\hline & Airplanes & Trains & $\begin{array}{l}\text { Hospital Delivery \& } \\
\text { Operating Rooms }\end{array}$ & $\begin{array}{l}\text { Office } \\
\text { Buildings }\end{array}$ & $\begin{array}{c}\text { School } \\
\text { Classroom* }\end{array}$ & $\begin{array}{l}\text { Typical School } \\
\text { Classroom }\end{array}$ & $\begin{array}{l}\text { Typical } \\
\text { Home }\end{array}$ \\
\hline & (Boeing, 2013) & (Boeing, 2013) & (Boeing, 2013) & (Boeing, 2013) & (ASHRAE, 2021) & (CMTA, 2020) & $\begin{array}{c}\text { (Aviation Public } \\
\text { Health Initiative, } \\
\text { 2020) }\end{array}$ \\
\hline & \multicolumn{7}{|c|}{ Typical Occupancy Level } \\
\hline & High & High & Medium & Medium & Medium/High & Medium/High & Low/Medium \\
\hline & \multicolumn{7}{|c|}{ Typical Air Changes per Hour (ACH) } \\
\hline $\begin{array}{l}\text { Ventilation } \\
\text { (Displaced Air } \\
\text { Indoors, with Air } \\
\text { from Outdoors) }\end{array}$ & $10-15$ & 8 & 5 & $1-2.5$ & $6-10$ & $4-6$ & 0.25 \\
\hline $\begin{array}{l}\text { HEPA Air } \\
\text { Filtration }\end{array}$ & $10-15$ & 6 & 20 & $3-7.5$ & 0 & 0 & 0 \\
\hline $\begin{array}{c}\text { Combined } \\
\text { (Ventilation }+ \\
\text { HEPA Air } \\
\text { Filtration) }\end{array}$ & $20-30$ & 14 & 25 & $4-10$ & $6-10$ & $4-6$ & 0.25 \\
\hline
\end{tabular}

*Updated Standard for COVID-19 Protection (ASHRAE, 2021). 
As shown in Table 3, the combined outside and filtered ACH of 20 - 30 in an airplane's cabin consists of 10 - 15 air changes from ventilation, i.e., outside air, and $10-15 \mathrm{ACH}$ of filtered air. This means that the air in an airplane cabin is completely refreshed 20 - 30 times an hour or once every 2 - $3 \mathrm{~min}$. The spread of the COVID-19 virus on airplanes should be limited only to those near an infected individual by way of droplet transmission (Morawska \& Cao, 2020). Hospitals rely mostly on filtered air ( $80 \%$ of total ventilation) for maintaining a virus-free environment.

As a result of the high ventilation rates in airplanes, in addition to mandatory masking requirements and disinfecting practices, the number of infection cases linked to flights has been low (Bielecki et al., 2020). During the week of January 11-17, 2021, only $0.25 \%$ of new COVID-19 cases in Canada were linked to air travel (Government of Canada, 2021a).

The primary virus transmission mode on a flight is via respiratory droplets, which only pose a risk to those seated nearby an infected individual (Khanh et al., 2020). Ensuring adequate and effective ventilation of the COVID-19 virus aerosols in many closed spaces is a challenge. The two main types of ventilation systems are: mixing ventilation systems and displacement ventilation systems. Mixing ventilation systems rely on fresh air being vented into the space to ensure mixing. Opening a window is a type of mixing ventilation. Displacement ventilation typically employs vents at ground level from which fresh air is brought into the space and exhaust vents near the ceiling that extract air out from the space. A research team from the University of Cambridge concluded that mixing ventilation systems could increase viral transmission by dispersing respiratory droplets and aerosols throughout the space (Brierley, 2020). Displacement ventilation systems have the most potential for countering the spread of the virus as they actively extract contaminated air from the space at a faster rate than natural mixing of the indoor air (Brierley, 2020). Furthermore, these researchers stressed that adequate ventilation systems are not in any way a viable substitution for face coverings, which should always be the primary defence against viral spread.

Due to the potential risk associated with airborne respiratory aerosols, the CDC recommends a maximum of only a 30-minute stay in virus-affected, unventilated areas (CDC, 2020b). Windows can be opened either intermittently or continuously as a way of ventilating indoor spaces. However, ventilating a closed space by opening windows in northern cold climates during winter is limited as an option for reducing the risk associated with airborne particulate concentrations and virus-laden aerosols. When access to ventilation is not possible or realistic, residents should opt for a HEPA air purifier (Ontario Labour Relations Board, 2021). Devices utilizing HEPA filtration technology, in theory, can capture $99.97 \%$ of particles with a $0.3 \mu \mathrm{m}$ diameter (Environmental Protection Agency, 2019). Capture efficiencies are at a minimum at this particle size. These efficiencies increase further for particle sizes either smaller or larger than $0.3 \mu \mathrm{m}$. 
Larger particles $(>0.3 \mu \mathrm{m})$ are primarily captured due to interception with the filter's fibres, while smaller particles $(<0.3 \mu \mathrm{m})$ are trapped mainly due to their diffusion after having moved through Brownian motion. In simple terms, Brownian motion can be described as microscopic random fluctuations exhibited by small particles as they interact with each other and the surrounding media in diffusing. Respiratory aerosols that can potentially carry the COVID-19 virus are 5 $\mu \mathrm{m}$ or smaller, meaning that their capture efficiency is at least $99.97 \%$ when passing through a HEPA filter. Air purifiers have also been proven to reduce the spread of the common flue and others viruses (Environmental Protection Agency, 2019).

\subsubsection{Air Purifiers}

More recent scientific findings support the position that air purifiers equipped with HEPA filtration can help reduce the spread of COVID-19 (Christopherson et al., 2020; Zhao et al., 2020; Mousavi et al., 2020; Curtius et al., 2020; Curtius et al., 2021). Mousavi et al. (2020) examined the performance of portable HEPA air purifiers used to isolate air in a hospital patient room from migration into exterior hallways. In their study, the patient's room was divided into two areas, an isolation room, where aerosol-generating equipment was located, and an anteroom, a dividing room used to separate the isolation room from the rest of the facility. The anteroom, in this case, was set up using a temporary plastic wall. The researchers found that the plastic wall alone, without the use of the air purifier, prevented up to $80 \%$ of the surrogate particles from spreading into the anteroom. With the addition of a HEPA air purifier in the isolation room, more than $99 \%$ of these particles were contained. The device removed the particles from the air inside the isolation room and discharged filtered air to the outdoors, thus creating negative pressure inside the isolation room and preventing the particles from escaping into adjacent spaces. Curtius et al. $(2020,2021)$ extensively studied HEPA air purifiers in a classroom setting. They concluded that using air purifiers in classrooms can be a practical strategy for reducing the risk of aerosolized transmission of the COVID-19 virus, especially when no fixed ventilation systems are installed and windows are not accessible (Curtius et al., 2021).

As of September 2021, Canada still considered the use of air purifiers as additional protection against the spread of the COVID-19 virus in situations where natural or mechanical ventilation and physical distancing are not possible (Government of Canada, 2021b). When used, air purifiers with HEPA filters are most effective when located close to the aerosol source (Lindsley et al., 2021). Although these devices capture airborne respiratory aerosols which may contain the COVID-19 virus, their impact on the trajectories of respiratory droplets is limited. Ham (2020) points out that air purifiers could potentially cause respiratory droplets to be suspended in the air longer and travel further. Thus, the air purifier's position in the room and its exhaust orientation play a crucial role in determining the risk associated with the dispersion of respiratory droplets. 


\subsubsection{The Case for HEPA Air Purifiers in Schools}

The use of air purifiers to reduce COVID-19 virus transmission in classroom settings has attracted the attention of both governments and researchers. In December 2020, one Quebec public school banned the use of air purifiers brought into classrooms by students (Henriquez, 2020). The Quebec Education Ministry noted that this ban was not official and indicated that maintaining and ensuring effective ventilation practices in the schools is the best strategy going forward (Henriquez, 2020). In early January 2021, the Quebec Minister of Health announced that air purifiers are not to be recommended officially as part of the reopening plan. Instead, opening windows regularly, social distancing, and mask-wearing should remain the primary strategies for stopping the spread of the virus.

According to Lurie and Ross (2021), reporting for CTV news, the decision by the Quebec public school division to ban the use of air purifiers in schools baffled many scientists and experts. In December 2020, the CDC recommended the use of air purifiers to mitigate the spread of the COVID-19 virus. Several accredited studies have already shown their efficacy (Burgmann \& Janoske, 2021; Curtius et al., 2021; Lindsley et al., 2021). One study from Germany concluded that HEPA air purifier use in classrooms makes students six times less likely to contract COVID-19 (Curtius et al., 2020).

By December 2020, most school boards in Quebec were still using their windows as the main line of defence against aerosolized spread of the COVID-19 virus. According to Mahoney and Perreaux (2020), some teachers even requested that students be prepared to dress warmly in the classrooms as temperatures were sure to drop with windows left open in the frigid weather. By January of 2021, Quebec requested that all classroom windows be left open for at least 10-15 minutes twice daily, as well as 30 minutes before and after each class (Mahoney \& Perreaux, 2020).

According to Fletcher \& Olivier (2021), nearly two out of three schools in Quebec currently depend on natural ventilation to prevent COVID-19 virus transmission in schools. Despite Quebec's official stance on air purifiers in classrooms, many of the largest school divisions in the province invested in HEPA air purifiers for their classrooms. Four months after the initial decision by the Quebec Minister of Health to opt against the use of air purifiers in schools, new data showed a substantial difference in case numbers between Quebec schools that incorporated HEPA air purifiers in their mitigation protocols and those which did not. Out of 677 schools in Quebec, the 61 schools that utilized HEPA air purifiers had, on average, 1.8 COVID-19 cases per school, whereas the 616 schools which did not utilize air purifiers had, on average, 7.3 COVID-19 cases per school (Ross, 2021).

In contrast to Quebec's recommendations, Public Health in Germany recommended intermittent window opening only during class with no requirement for window ventilation between class periods (Deutsche Welle, 2020, October 10). Curtius et al. (2020) studied the effectiveness of utilizing Germany's practice of 
intermittent window opening, as well as the use of HEPA air purifiers during class. These researchers modelled various strategies for reducing the concentration of RNA-containing aerosols in a classroom. The use of four air purifiers with HEPA filtration and a total clean air delivery rate (CADR) of $1026 \mathrm{~m}^{3} / \mathrm{h}$ was incorporated into their model. The classroom size was $180 \mathrm{~m}^{3}$, and the air purifiers had a CADR rating equivalent to $\mathrm{ACH}=5.7$. This is slightly below the American Society of Heating and Air-Conditioning Engineers (ASHRAE) recommendation of an ACH of at least 6 for schools (ASHRAE, 2020).

Figure 2 shows the concentration of the RNA-containing aerosol in a German classroom over a series of 60 -min classes, each followed by a 30 -min break, as modelled by Curtius et al. (2020). One student, who has two successive classes in the same room that day, is assumed to be infected with COVID-19. Natural ventilation in the Curtius et al. (2020) model was assumed to be achieved by opening windows for 3 minutes every 20 minutes, achieving a reduction of either 30\% or $99 \%$ of the existing virus-containing aerosol during the 3-min period of ventilation. The mitigation potential of windows accessed intermittently depends on

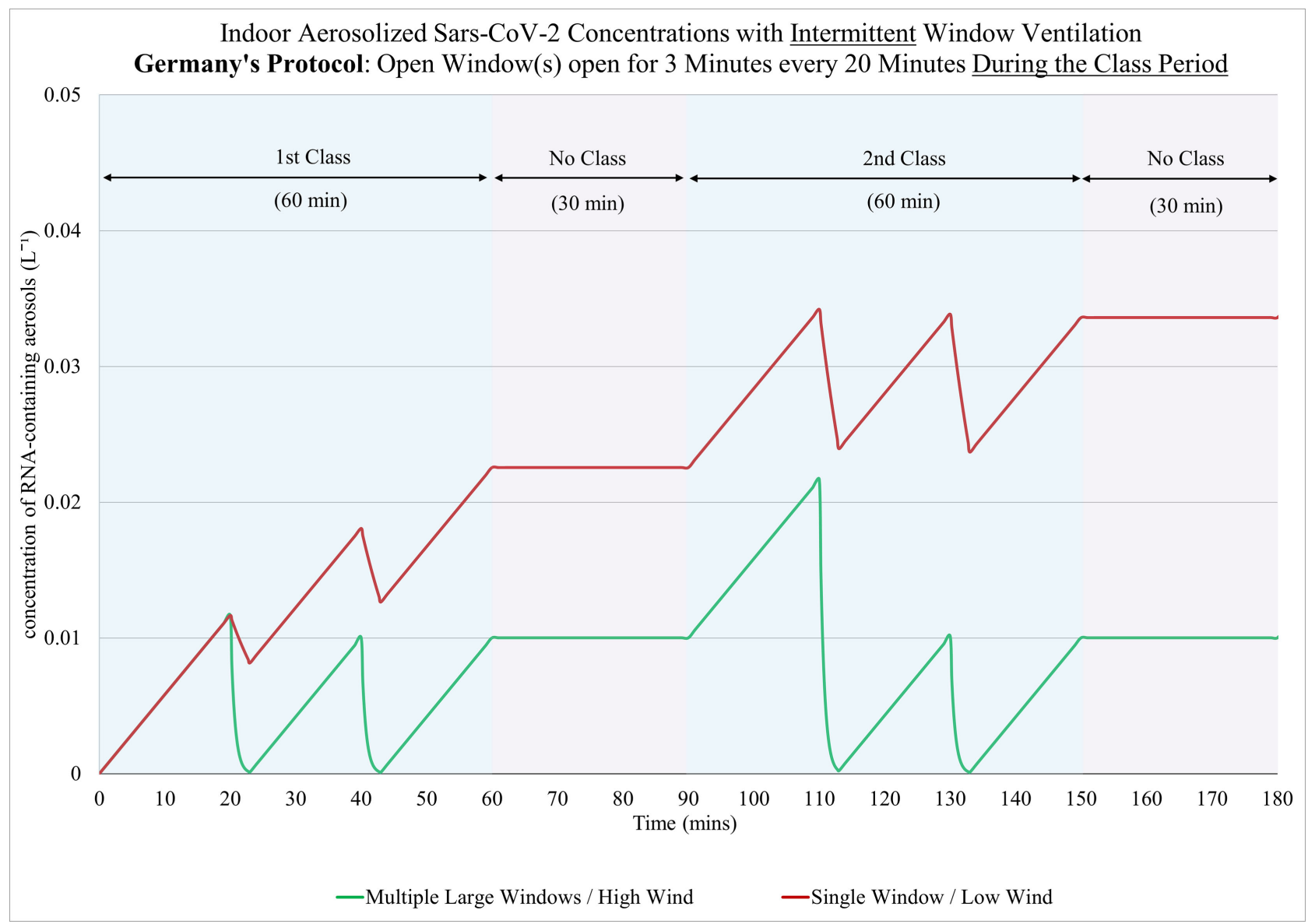

Figure 2. Germany's intermittent window ventilation protocol for classrooms: Window(s) open for 3 min, every 20 min during Class (adapted from Curtius et al., 2020). Note: Single Window/Low Wind assumes a 30\% airborne viral concentration reduction every $3 \mathrm{~min}$ that the window is left open. Multiple Large Windows/High Wind assumes a 99\% airborne viral concentration reduction every $3 \mathrm{~min}$ that the window is left open. 
the number of windows, their size, wind conditions, and temperature differentials between the outdoor and indoor spaces. To achieve the $99 \%$ reduction in concentration, Curtius et al. (2020) assumed that the classroom must have multiple large windows, each of which is operable, high-wind conditions, and a significant temperature differential between the indoor classroom and the outdoors. To achieve a 30\% concentration reduction, Curtius et al. (2020) assumed that the classroom had a single operable window, low wind conditions, and a minimal temperature differential between the indoor classroom and the outdoors.

Figure 2 further shows that a partial level of ventilation (resulting in a 30\% reduction in the virus-containing aerosol over a 3-min period, every $20 \mathrm{mi}$ nutes) is insufficient to mitigate the amount of COVID-19 aerosol dispersed during the previous $20 \mathrm{~min}$ that the windows were closed. A step-like escalation in aerosol concentrations results over the 60-min class period and throughout the day. However, this escalation can be avoided entirely if a much higher level of ventilation is applied (e.g., one that would result in a $99 \%$ reduction in aerosol concentration over the same 3-min period every $20 \mathrm{~min}$ ). Such a drastic drop in the concentration requires access to multiple large operable windows and favourable weather conditions, which may not always be possible. This high level of ventilation is used in the current study to gauge the mitigation potential of both Germany's and Quebec's intermittent window ventilation strategies.

The Curtius et al. (2020) model was extended in this paper to examine the concentration of the RNA-containing aerosol in Quebec's school ventilation protocol. Quebec's school strategy requires that windows and doors be left open for 30-min before and after class. Again, the model assumes that an infectious person is present during each class period, no mechanical ventilation systems are in place, and no HEPA air purifiers are used at all. The results are shown in Figure 3.

The results shown in Figure 3 indicate that, while this ventilation practice is effective in reducing the concentration of the virus-containing aerosol considerably over the $30-\mathrm{min}$ period between classes, the concentration begins to rise again during class as the students are continuously exposed to an infectious individual, and no ventilation mitigation is practised during class.

This model was further expanded in this paper to include the effect of HEPA air purifiers in order to characterize their impact on reducing the concentration of the virus-containing aerosol, both alone and in combination with different intermittent window ventilation strategies. The results are shown in Figure 4 and Figure 5. These results indicate that introducing a HEPA air purifier, in addition to ventilation, consistently offers an additional layer of protection against virus-laden aerosol concentrations. Moreover, their presence ensures that any escalation in COVID-19 virus-laden aerosol concentration between classes can be effectively avoided. For both models, an infectious person is assumed to be present during each class period, no mechanical ventilation systems are installed, 
and several HEPA air purifiers are run continuously throughout the day. A combined air exchange rate $(\mathrm{ACH})$ of the air purifier(s) $=5.7$ was assumed, which is the same as that used by Curtius et al. (2020).

In contrast to intermittent ventilation strategies, continuous ventilation, such as that provided by mechanical HVAC systems or by leaving windows/doors open at all times, ensures a continual and sharp reduction in indoor virus-laden aerosol concentrations, both before and during the class period.

Like HVAC systems, HEPA-equipped air purifiers provide continuous mitigation and are relatively less expensive than HVAC systems. As pointed out by Curtius et al. (2020), utilizing multiple HEPA air purifiers simultaneously in an indoor space offers cumulative performance, as measured by the total CADR or ACH. Notably, Quebec Public Health still does not recommend using portable air purifiers as a primary means for mitigating aerosolized COVID-19 virus. Quebec has since updated its window access strategy to request that windows in school classrooms be kept open at all times, if possible (Government of Quebec, 2021).

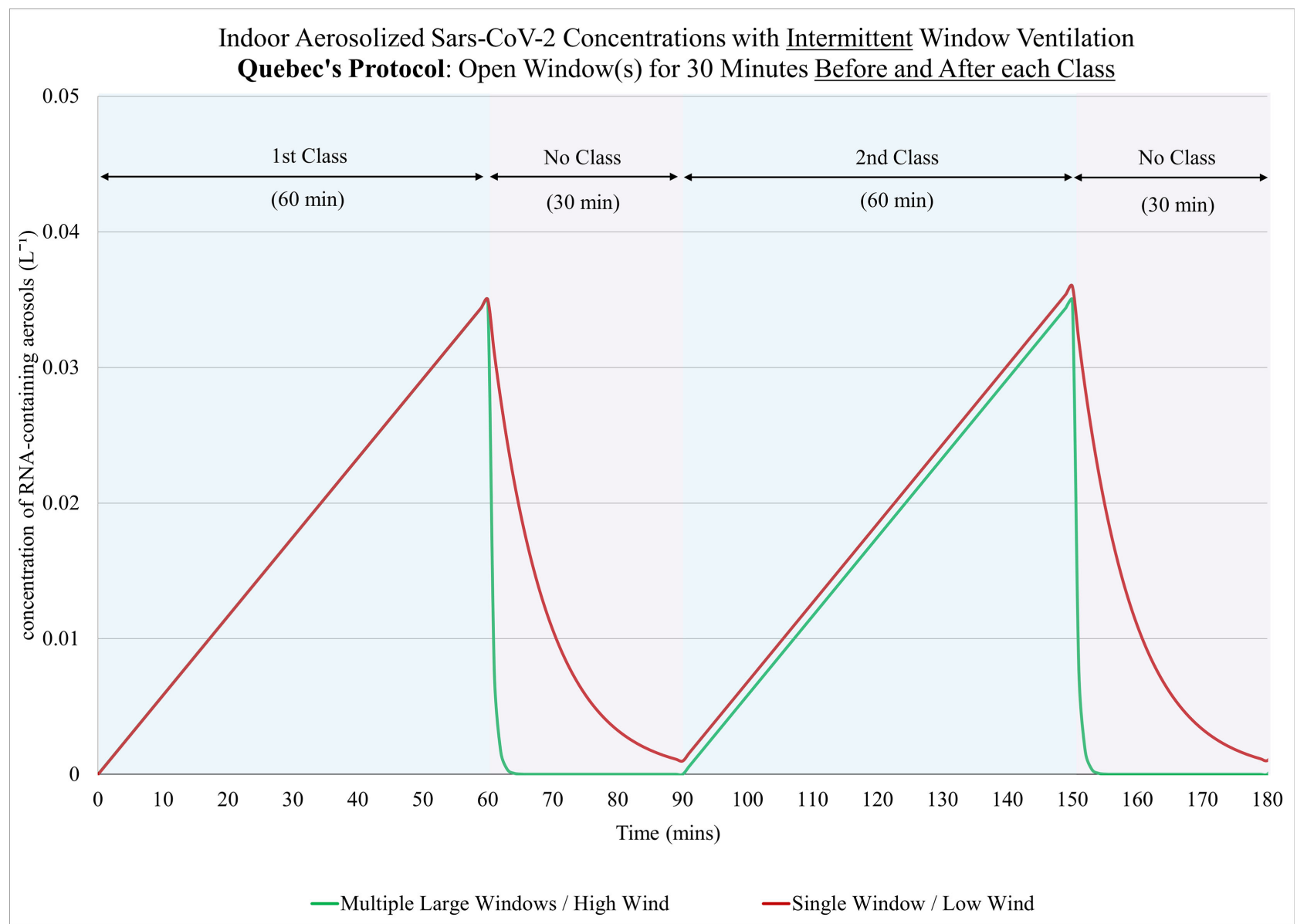

Figure 3. Quebec's intermittent window ventilation protocol for classrooms: Window(s) open for 30 min before and after class (adapted from Curtius et al., 2020). Note: Single Window/Low Wind assumes a 30\% airborne viral concentration reduction every 3 min that the window is left open. Multiple Large Windows/High Wind assumes a $99 \%$ airborne viral concentration reduction every $3 \mathrm{~min}$ that the window is left open. 


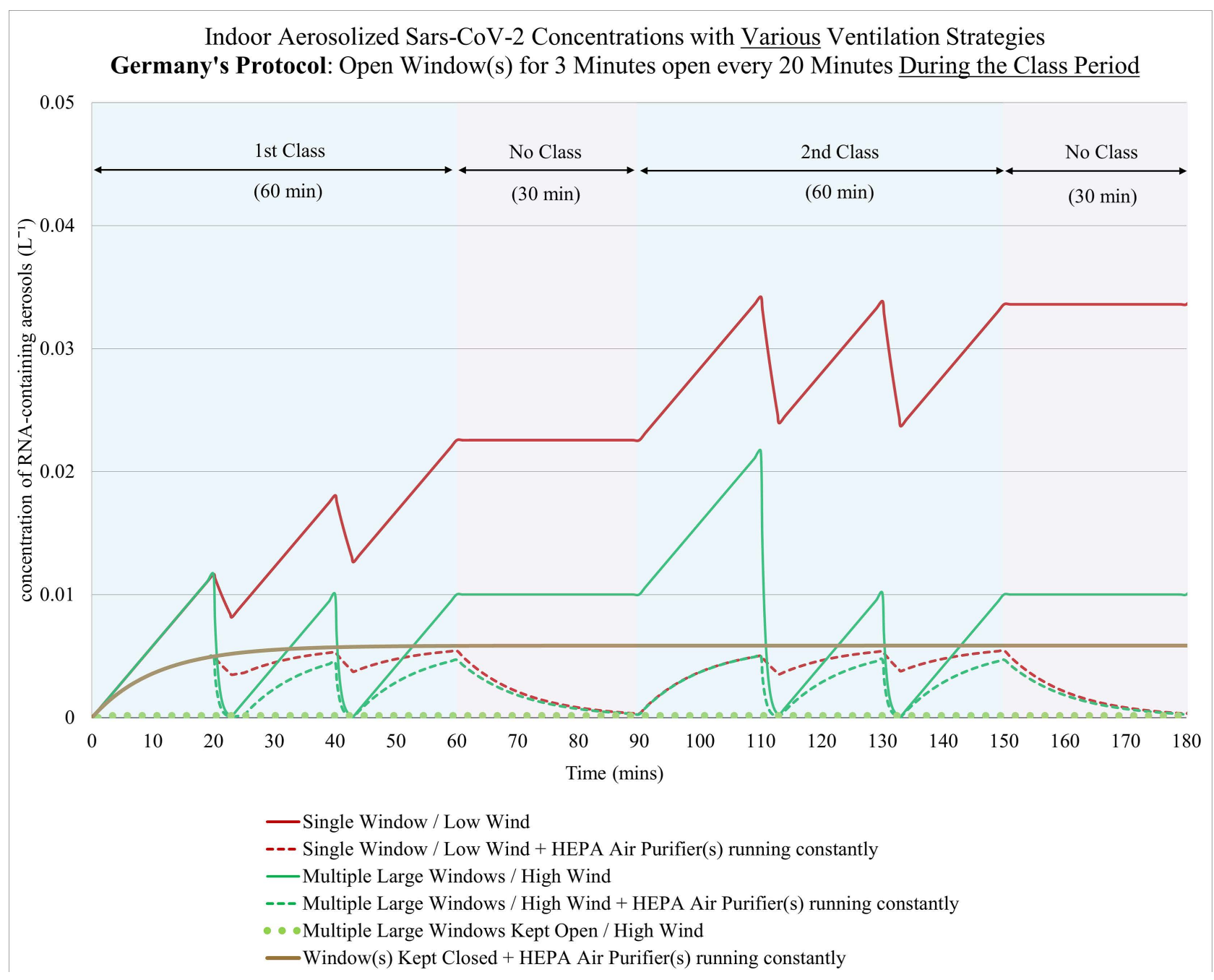

Figure 4. Germany's intermittent window ventilation protocol for classrooms: Window(s) open for 3 min every 20 min during class-additionally including the use of HEPA air purifiers/continuous window ventilation (adapted from Curtius et al., 2020). Note: Single Window/Low Wind assumes a 30\% airborne viral concentration reduction every 3 min that the window is left open. Multiple Large Windows/High Wind assumes a 99\% airborne viral concentration reduction every 3 min that the window is left open. Multiple Large Windows Kept Open/High Wind assumes a continuous ventilation rate resulting in a 99\% airborne viral concentration reduction every 3 min.

In addition to the concentration of the RNA-containing aerosol, Curtius et al. (2020) examined the dose of RNA copies inhaled by a susceptible person over a one-hour period for various scenarios of ventilation (see Table 4). Table 4 shows that a combination of good ventilation and the use of HEPA air purifiers provides occupants with the most protection against aerosolized COVID-19 virus. In rooms with limited ventilation (poor or some), HEPA air purifiers significantly improve protection.

Ranking mitigation protocols by the viral dose absorbed over an hour-long period in a classroom setting can be used to evaluate further virus transmission associated with human behaviour in comparably sized and occupied indoor spaces. This evaluation is discussed in Section 3.3.

Figure 4 and Figure 5 show that HEPA air purifiers, used in combination 
with good ventilation practices, offer a high level of mitigation against aerosolized spread. However, opening a window could potentially elevate the overall transmission risk, in a similar fashion described by Ham (2020), if a wind draft causes respiratory droplets, which generally fall abruptly to the ground, to remain airborne for extended periods of time. The precise nature of the overall risk associated with indoor aerosolized and droplet transmission of the COVID-19 virus when HEPA air purifiers and windows are utilized has yet to be comprehensively examined. However, it is clear that without either ventilation or HEPA air purification, respiratory aerosols remain airborne indoors for much longer periods than the maximum time recommended by the CDC (30 minutes) for anyone to remain in a non-ventilated space.

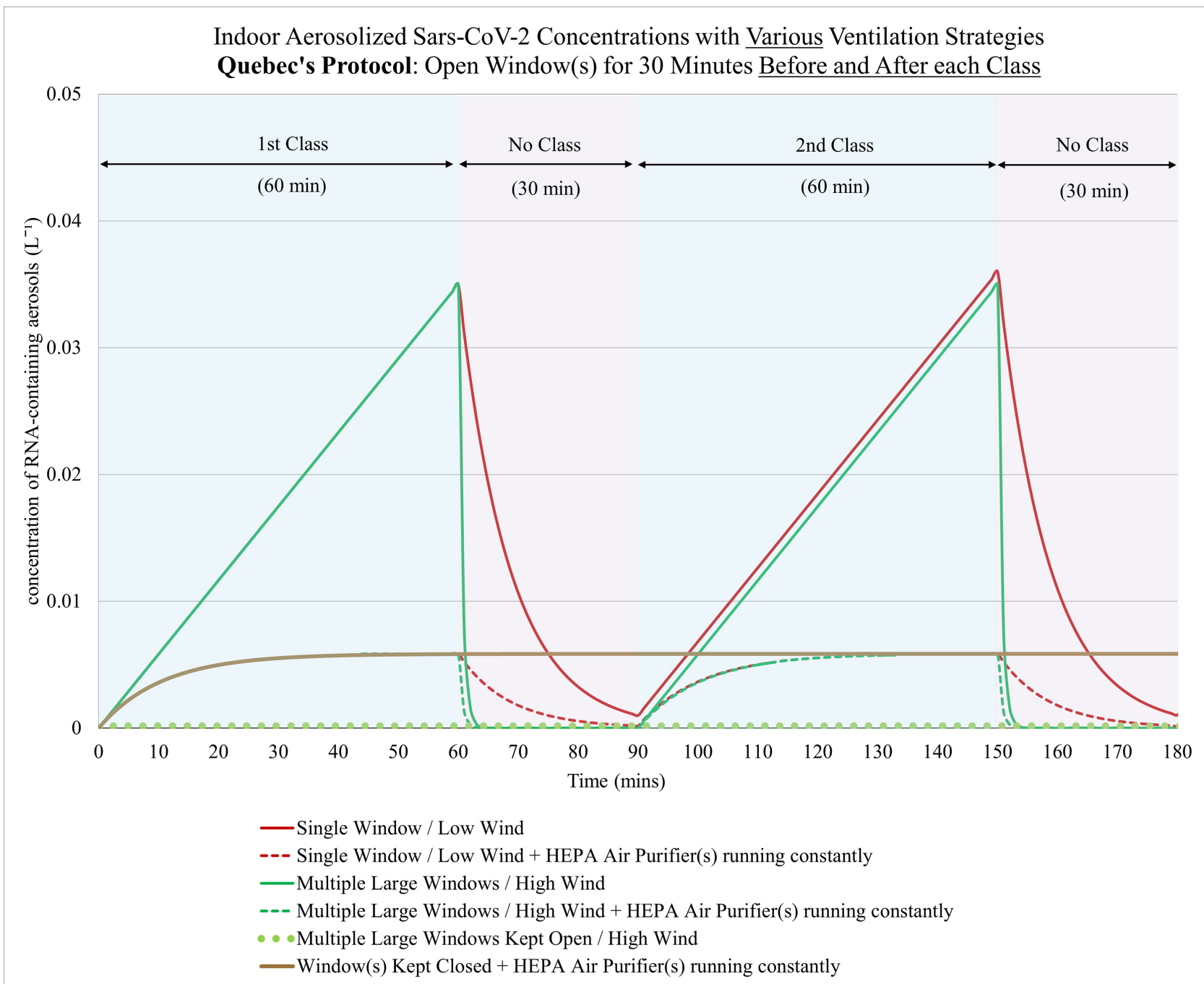

Figure 5. Quebec's intermittent window ventilation protocol for classrooms: Window(s) open for 3 min every 20 min during class-additionally including the use of HEPA air purifiers/continuous window ventilation (adapted from Curtius et al., 2020). Note: Single Window/Low Wind assumes a 30\% airborne viral concentration reduction every 3 min that the window is left open. Multiple Large Windows/High Wind assumes a 99\% airborne viral concentration reduction every 3 min that the window is left open. Multiple Large Windows Kept Open/High Wind assumes a continuous ventilation rate resulting in a $99 \%$ airborne viral concentration reduction every $3 \mathrm{~min}$. 
Table 4. Approximate and normalized dose (number of COVID-19 virus RNA copies) inhaled by a susceptible individual in a classroom exposed to an infectious individual over a one-hour period with and without the use of HEPA air purifiers under different ventilation scenarios (based on Curtius et al. (2020)).

\begin{tabular}{|c|c|c|c|c|c|c|}
\hline & \multicolumn{6}{|c|}{ Normalized Dose (Number of COVID-19 virus RNA Copies per Hour) (Normalized to Case F) } \\
\hline & \multicolumn{2}{|c|}{ Poor Ventilation* } & \multicolumn{2}{|c|}{ Some Ventilation ${ }^{* *}$} & \multicolumn{2}{|c|}{ Good Ventilation ${ }^{* * *}$} \\
\hline & $\begin{array}{c}\text { Base } \\
\text { (No Air Purifier) }\end{array}$ & $\begin{array}{l}\text { With HEPA } \\
\text { Air Purifier }\end{array}$ & $\begin{array}{c}\text { Base } \\
\text { (No Air Purifier) }\end{array}$ & $\begin{array}{l}\text { With HEPA } \\
\text { Air Purifier }\end{array}$ & $\begin{array}{c}\text { Base } \\
\text { (No Air Purifier) }\end{array}$ & $\begin{array}{l}\text { With HEPA } \\
\text { Air Purifier }\end{array}$ \\
\hline Case & A & B & $\mathrm{C}$ & $\mathrm{D}$ & $\mathrm{E}$ & $\mathrm{F}$ \\
\hline Dose Absorbed $\left(\mathrm{h}^{-1}\right)$ & 5.20 & 1.50 & 3.42 & 1.30 & 1.50 & 0.90 \\
\hline Normalized & 5.78 & 1.67 & 3.80 & 1.44 & 1.67 & 1.00 \\
\hline Effectiveness Rank & & & & & & \\
\hline $\begin{array}{l}\text { 1-Best } \\
\text { 5-Worst }\end{array}$ & 5 & 3 & 4 & 2 & 3 & 1 \\
\hline
\end{tabular}

Note: Ventilation is achieved with intermittent window access in a classroom setting. ${ }^{\star}$ Poor Ventilation: $0 \%$ airborne viral concentration reduction over a 3 -min period (window not opened). ${ }^{*}$ Some Intermittent Ventilation: 30\% airborne viral concentration reduction over a 3 -min period every 20 min. ${ }^{* * *}$ Good Intermittent Ventilation: $99 \%$ airborne viral concentration reduction over a 3-min period, every $20 \mathrm{~min}$.

Even if masks are worn indoors, an inherent risk is associated with aerosolized spread without proper ventilation or air purification. Out of the 26 largest school boards across Canada contacted by the Globe and Mail in December 2020, only eight had opted to install HEPA air purification units in classrooms (Mahoney \& Perreaux, 2020). As of July 2021, schools in Winnipeg, Saskatoon, and Calgary currently have no plans for introducing similar systems in their schools.

Scientific evidence shows that air purifiers utilizing HEPA filters, together with good ventilation, effectively reduce aerosolized particles in a classroom setting (Curtius et al., 2020; Han et al., 2020; Bullister, 2021). Combined with mask use, these strategies counter the spread of COVID-19 even more effectively than social distancing alone (Foster \& Kinzel, 2021).

\subsubsection{Mathematical and Computational Fluid Dynamics (CFD) Approaches Used to Simulate the Spread of Infectious Aerosols or Droplets}

Researchers often use the simple mathematical Wells-Riley model to simulate the spread of the COVID-19 virus within an indoor space to estimate infection probability (Foster \& Kinzel, 2021; Noakes \& Sleigh, 2008). This model, however, is limited in that it does not account for complex stochastic particle behaviour arising within the indoor space. Instead, it assumes complete indoor air mixing, implying uniformity of infectious aerosols (Noakes \& Sleigh, 2008; Foster \& Kinzel, 2021). As a result, Wells-Riley models do not provide insight on potential localized risk zones that may arise within the indoor space itself (Noakes \& Sleigh, 2009). Similarly, the model developed by Curtius et al. (2020) assumes perfect mixing of the indoor air at all times and, therefore, does not help describe aerosolized risk variance within the classroom space itself. The risk of infection in a real-world environment will not always be uniform within a given space. Depending on where occupants reside within the space, infection transmission routes can vary significantly (Foster \& Kinzel, 2021). However, 
these models allow researchers to easily rank mitigation strategies employed in an indoor space (Foster \& Kinzel, 2021).

A number of researchers have used computational fluid dynamics (CFD) approaches to obtain a clearer understanding of how COVID-19 aerosols spread locally inside a classroom setting. Burgmann \& Janoske (2021), for example, used the Numerical CFD code OpenFOAM ${ }^{\circledR}$ to examine the effectiveness of a HEPA air purifier in reducing the concentration of aerosols in a classroom. Abuhegazy et al. (2020) used computational fluid-particle dynamics simulations to study the spread of aerosol from an infected individual in a classroom environment and the effectiveness of glass partitions and window openings as a way of reducing aerosol transmission. Narayanan and Yang (2021) used the Eulerian-Lagrangian approach to examine the effectiveness of portable air purifiers to reduce the concentration of aerosolized COVID-19 virus in a music classroom. Pavilonis et al. (2021) examined the risk of SARS-CoV-2 transmission among students and teachers in 19 schools in New York using a modified Wells-Riley equation under both steady-state and varying exposure conditions. The researchers found that the mean probability of transmission was generally low, which they attributed to the fact that the study was conducted between December 2017 and September 2018, before the surge of SARS-CoV-2 in New York City. Foster \& Kinzel (2021) used mathematical (Wells-Riley) and numerical CFD methods to examine the probability of infection in a typical classroom scenario with masked individuals. They found that both methods predicted a $40 \%-50 \%$ lower risk of infection when ventilation, in combination with filtration, was used.

The research addressing the spread of aerosols inside a classroom setting is predominantly theoretical (Mirzaie et al., 2021). However, some experimental evidence is available. Burgmann \& Janoske (2021), for example, used artificially generated aerosol to examine the effectiveness of a HEPA air purifier in reducing the concentration of aerosols in classrooms. The reduction in concentration ranged between $70 \%$ and $90 \%$ depending on the location when an $\mathrm{ACH}$ of 6 was applied. Curtius et al. (2020) conducted both theoretical and experimental examination of the efficiency and practicability of operating four air purifiers equipped with HEPA filters in a high school classroom during regular classes. They observed that, with windows and doors closed, the aerosol concentration in the classroom was reduced by more than $90 \%$ within less than 30 min when running the purifiers $(\mathrm{ACH}=5.7)$.

The computational fluid mechanics approach in modelling droplet motion and distribution is well-documented in the fluid mechanics literature (Dolatabadi et al., 2021; Hoseinzade et al., 2021; Yazdani \& Lakzian, 2020; Foroozeh et al., 2020; Hosseini \& Lakzian, 2020). Several researchers have also used a CFD approach to examine the distribution of airborne COVID-19 virus droplets, under various environmental conditions, in school as well as in other environments. For example, Mirzaie et al. (2021) used a 3D turbulence model and a Langrangian particle trajectory analysis method to track the motion and dispersion of cough droplets by an infected individual in front of a classroom. One of the pa- 
rameters tested was the use of transparent barriers placed in front of the seats to reduce the concentration of droplets. The researchers found this intervention to be "somewhat effective." D'Alessandro et al. (2021) and Motamedi Zoka et al. (2021) used the Eulerian-Lagrangian CFD approach to simulate the distribution of infectious exhaled droplets in various environments.

The airborne dispersion of particles due to various indoor human activities (i.e., coughing, singing) was the subject of study by Mariam et al. (2021) and Rosti et al. (2020), who used CFD to study the safe distance for the transmission of the COVID-19 virus. Mariam et al. (2021) used the Reynolds-Averaged Navier-Stokes (RANS)-CFD approach, while Rosti et al. (2020) used a Lagrangian model. Mesgarpour et al. (2021) used a combined CFD and artificial intelligence (AI) approach to study the spread of droplets produced by a sneezing passenger in a bus. The results showed that the concentration of droplets could decline to $87 \%$ in the first $3 \mathrm{~m}$.

\subsection{Risk of Virus Transmission Associated with Human Behaviour}

The model developed by Curtius et al. (2020) provides an effective way of gauging the risk associated with various ventilation strategies in a classroom. However, Curtius et al.'s model does not consider the level of human behaviour in this setting. Another group of researchers from Oxford University developed a simple chart to summarize the risks associated with different human behaviours: singing, speaking, and shouting, in enclosed indoor spaces with varying occupancies (Jones et al., 2020). According to this chart, the risk of transmission is low or moderate when wearing face coverings in low-occupancy environments and when being silent or just speaking. The risk is high in poorly ventilated spaces if shouting or singing occurs.

Figure 6 characterizes the risk associated with exposure to the COVID-19 virus with different group activities indoors and under varying occupancy levels. Its purpose is to portray the overall effect of the various aerosol mitigation practices examined thus far in abating viral transmission. The chart is based on the work of Jones et al. (2020), modified in this paper to consider the use of HEPA air purifiers and intermittent window ventilation indoors. A classroom setting, as addressed in Figure 2 and Figure 4, is chosen as the indoor space. Each mitigation strategy is ranked according to its mitigation potential as measured primarily by its impact on aerosolized COVID-19 virus concentrations and inhaled doses over an hour-long class period.

Average $\mathrm{ACH}$ values were also included for each mitigation strategy. However, $\mathrm{ACH}$ values alone do not offer a complete picture in assessing the effect of intermittent ventilation. This is because average $\mathrm{ACH}$ values over the class period depend only on the duration of time a window is opened, or a HEPA air purifier is running. In contrast, aerosolized COVID-19 concentrations and inhaled viral doses depend on both when and how long the windows are left open. Other factors contributing to the aerosolized concentrations in a room include 


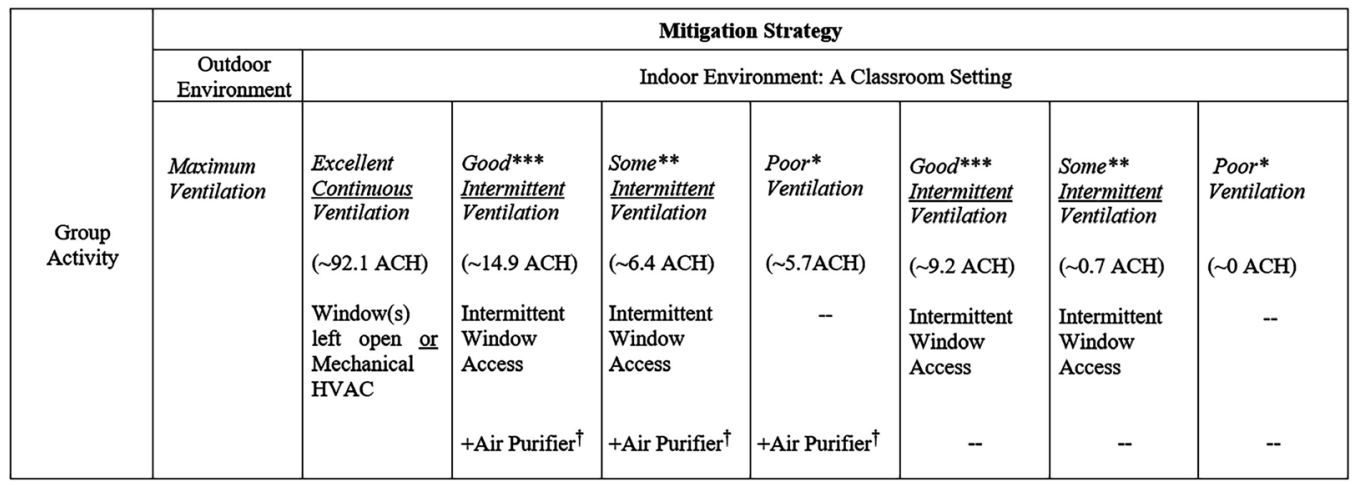

High Occupancy

\begin{tabular}{|c|c|c|c|c|c|c|c|c|c|}
\hline Breathing & 0 & 0 & 1 & 2 & 3 & 3 & 4 & 5 & \multirow{3}{*}{ 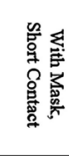 } \\
\hline Speaking & 0 & 0 & 1 & 2 & 3 & 3 & 4 & 5 & \\
\hline $\begin{array}{l}\text { Shouting, } \\
\text { Singing }\end{array}$ & 5 & 5 & 6 & 7 & 8 & 8 & 9 & 10 & \\
\hline Breathing & 0 & 5 & 6 & 7 & 8 & 8 & 9 & 10 & \multirow{3}{*}{ 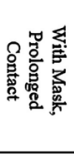 } \\
\hline Speaking & 5 & 5 & 6 & 7 & 8 & 8 & 9 & 10 & \\
\hline $\begin{array}{l}\text { Shouting, } \\
\text { Singing }\end{array}$ & 5 & 10 & 10 & 10 & 10 & 10 & 10 & 10 & \\
\hline Breathing & 5 & 5 & 6 & 7 & 8 & 8 & 9 & 10 & \multirow{3}{*}{ 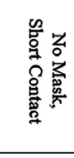 } \\
\hline Speaking & 5 & 10 & 10 & 10 & 10 & 10 & 10 & 10 & \\
\hline $\begin{array}{l}\text { Shouting, } \\
\text { Singing }\end{array}$ & 10 & 10 & 10 & 10 & 10 & 10 & 10 & 10 & \\
\hline Breathing & 5 & 10 & 10 & 10 & 10 & 10 & 10 & 10 & \multirow{3}{*}{ 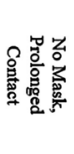 } \\
\hline Speaking & 10 & 10 & 10 & 10 & 10 & 10 & 10 & 10 & \\
\hline $\begin{array}{l}\text { Shouting, } \\
\text { Singing }\end{array}$ & 10 & 10 & 10 & 10 & 10 & 10 & 10 & 10 & \\
\hline
\end{tabular}

Low Occupancy

\begin{tabular}{|c|c|c|c|c|c|c|c|c|c|}
\hline Breathing & 0 & 0 & 0 & 0 & 0 & 0 & 0 & 0 & 2 \\
\hline Speaking & 0 & 0 & 0 & 0 & 0 & 0 & 0 & 0 & 83 \\
\hline $\begin{array}{l}\text { Shouting, } \\
\text { Singing }\end{array}$ & 0 & 0 & 1 & 2 & 3 & 3 & 4 & 5 & \\
\hline Breathing & 0 & 0 & 1 & 2 & 3 & 3 & 4 & 5 & \multirow{3}{*}{ 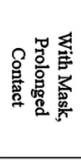 } \\
\hline Speaking & 0 & 0 & 1 & 2 & 3 & 3 & 4 & 5 & \\
\hline $\begin{array}{l}\text { Shouting, } \\
\text { Singing }\end{array}$ & 0 & 5 & 6 & 7 & 8 & 8 & 9 & 10 & \\
\hline Breathing & 0 & 0 & 1 & 2 & 3 & 3 & 4 & 5 & \multirow{3}{*}{ 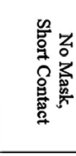 } \\
\hline Speaking & 0 & 5 & 5 & 5 & 5 & 5 & 5 & 5 & \\
\hline $\begin{array}{l}\text { Shouting, } \\
\text { Singing }\end{array}$ & 5 & 5 & 6 & 7 & 8 & 8 & 9 & 10 & \\
\hline Breathing & 0 & 5 & 6 & 7 & 8 & 8 & 9 & 10 & \multirow{3}{*}{ 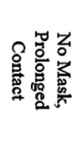 } \\
\hline Speaking & 5 & 5 & 6 & 7 & 8 & 8 & 9 & 10 & \\
\hline $\begin{array}{l}\text { Shouting, } \\
\text { Singing }\end{array}$ & 5 & 10 & 10 & 10 & 10 & 10 & 10 & 10 & \\
\hline
\end{tabular}

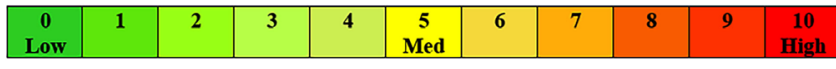

Legend: Comparative Risk of Transmission

Figure 6. Comparative risk of transmission (greater or less than) of the COVID-19 virus (SARS-CoV-2), for different group activities, in both outdoor and indoor environments, and under specific conditions including the extent of ventilation in the room, the $\mathrm{ACH}$, use of a HEPA air purifier, access to windows, mask-wearing by the individual, duration of contact with another infected individual, and the level of space occupancy (based on Jones et al., 2020). 
the number of infected individuals, the presence/absence of air purifiers, and the capacity of the HVAC system.

Risk levels shown in Figure 6 were expanded from the original three risk ranks (green $=$ low, yellow $=$ medium, red $=$ high), developed by Jones et al. (2020), to 11 risk ranks, in order to differentiate among risks across additional mitigation strategies. For spaces "indoors and well-ventilated," we assumed that high-level, continuous ventilation is being utilized, either by leaving multiple windows open or by having a mechanical HVAC system in place. The "poorly-ventilated" classification implies that ventilation practices and HEPA air purifiers are not being utilized.

The level of risk of transmission associated with each mitigation strategy, listed in Figure 6, is not absolute but rather relative to each other. Risk values follow a simple ranking system. Thus, the scale for COVID-19 viral transmission in increasing levels of risk is as follows: $0=$ low risk, $5=$ medium risk, and $10=$ high risk. The higher the number, the higher the risk. The modified ranking of the mitigation strategies shown in Figure 6 was based on the RNA dosage data by Curtius et al. (2020), shown in Table 4. For example, individuals exposed to an infectious person in a room with no HEPA air purifiers but with some ventilation received 3.42 RNA copies per hour (see Table 4). These individuals were assigned a risk of exposure value of 4 (see Figure 6). On the other hand, individuals exposed to an infectious person in a room with HEPA air purifiers and with some ventilation received 1.30 RNA copies per hour (see Figure 4). These individuals were assigned a risk of exposure value of 2 (see Figure 6). The risk assessments shown in Figure 6 are estimates and are not intended as medical or public health advice.

Occupancy has a direct impact on the risk associated with COVID-19 viral transmission. As shown in Figure 6, residing in indoor spaces with high occupancy levels without the use of masks is a high risk, irrespective of the contact time or level of group activity. Any shouting or singing in proximity to others requires masks to provide adequate protection against transmission of the virus regardless of ventilation or purification indoors. Except for breathing or speaking, any high occupancy indoor activity should be avoided without a mask. The spread of the virus in low-occupancy spaces indoors depends on the level of activity. Figure 6 shows that the indoor space is safe if HEPA air purifiers are used in combination with both intermittent window ventilation and masks, as long as no shouting or singing takes place for prolonged periods. Any outdoor activity with low occupancy is safe with or without a mask. A mask, however, is recommended when shouting or singing takes place in proximity to others.

\section{Recommendations}

Based on the analyses conducted as part of this paper, including findings from Curtius et al. (2020) and Jones et al. (2020), the following practical recommendations are suggested to counter the spread of the COVID-19 virus more effec- 
tively.

1) Ensure that indoor spaces are well-ventilated to contain the spread of aerosolized $(<5 \mu \mathrm{m})$ COVID-19 virus (SARS-CoV-2).

2) Install and run HEPA air purifiers in any space you suspect is either poorly ventilated or has limited access to intermittent ventilation before and during the time the space is occupied. If no HEPA air purifiers are available or no natural ventilation is possible, significantly reduce the time spent in this indoor space.

3) Install and run multiple HEPA air purifiers whenever possible, as their mitigation potential is cumulative. The total performance is the sum of the CADRs of the individual air purifiers.

4) Supplement ventilation with the use of HEPA air purifiers whenever possible as this provides an additional layer of protection against aerosolized $(<5 \mu \mathrm{m})$ transmission of the COVID-19 virus, irrespective of the level of ventilation present.

5) Be aware that HEPA air purifiers add little to no additional protection against droplet $(>5 \mu \mathrm{m})$ transmission. To best mitigate droplet transmission, masks should be used at all times, and social distancing practised.

In July 2021, new developments came to light surrounding the transmission risk of the now dominant Delta variant of the COVID-19 virus (B.1.617.2), initially detected in India. Unlike with the earlier variants (Thompson et al., 2021), the protection offered by the vaccine is less robust against the viral transmission of the new Delta variant (Brown et al., 2021; Bernal et al., 2021). Although the disease severity is significantly and successfully reduced in vaccinated individuals, the vaccine is shown in cases to offer limited protection against transmission of the Delta variant (Brown et al., 2021; Aravindan \& Lin, 2021; Ministry of Health of Israel, 2021). These developments prompted the CDC to reaffirm once again the benefits of wearing masks indoors, regardless of vaccination status (CDC, 2021). Moreover, many remain unvaccinated or partially vaccinated and remain at risk of developing severe illness. This recent development further underscores the urgency surrounding the adoption of sound mitigation protocols, especially in indoor settings with high occupancy levels, where there is inherently an elevated risk of infection.

\section{Conclusion}

The debate among scientists and health officials regarding the mode of COVID-19 virus transmission has impacted the approach taken by various levels of government to counter the spread of the virus. During the early stages of the pandemic, the CDC and the WHO concluded that infections occurred mainly through exposure to respiratory droplets and recommended social distancing, mask-wearing, disinfecting surfaces, and avoiding crowds. Only much later did they acknowledge the aerosolized transmission of the virus and recommend ventilation and the use of HEPA air purifiers. To develop an effective mitigation strategy, we reviewed the relevant literature assessing the use of ventilation and HEPA air purifiers for mitigating the spread of the aerosolized COVID-19 virus. Scientif- 
ic evidence shows that air purifiers equipped with HEPA filters, combined with other types of ventilation, effectively reduced aerosolized spread of the COVID-19 virus.

The use of windows as a means of ventilation is not possible for every classroom, or other indoor spaces, especially during the winter months. Mechanical ventilation systems (HVAC), on the other hand, offer continuous ventilation within an indoor space without undermining thermal comfort. However, high labour and equipment costs associated with the installation of mechanical ventilation systems may be prohibitive. Individual-level and practical solutions to mitigating the spread of the COVID-19 virus are of high importance, especially with the emergence of many new, highly transmissible variants.

Varying levels of continuous and/or intermittent ventilation, either mechanical or natural, combined with the use of HEPA air purifiers, provide a higher degree of protection than window access alone. The maximum level of ventilation offered by windows at any given time is limited by weather conditions and building design and is inherently uncontrollable. What can be managed, however, is how long windows are left open, a parameter which critically affects the mitigation potential for any indoor space. For maximum protection indoors, all windows should be kept open at all times. If, for any reason, window ventilation must remain intermittent in nature, a hybrid approach with the use of HEPA air purifiers is strongly recommended. Systematic deployment of a hybrid mitigation strategy incorporating both ventilation and HEPA air purification in schools, offices, or other facilities could potentially help in a practical way to establish a safe re-opening of society in Canada. The widespread adoption of effective yet practical mitigation solutions is especially important today because the highly transmissible Delta variant is the dominant COVID-19 virus strain plaguing Canadian communities.

We conclude that mitigation strategies adopted by governments, school boards, and the general public must, whenever at all possible, include the use of 1) masks indoors, 2) mechanical ventilation (HVAC) with HEPA filters, 3) natural ventilation by opening windows, 4) HEPA air purifiers in unventilated or poorly ventilated spaces, and 5) hybrid mitigation strategies incorporating both natural ventilation and HEPA air purification, which has the potential to offer even more protection.

In addition, government recommendations should be adapted to include detailed air purification protocols to more effectively counter the aerosolized $(<5$ $\mu \mathrm{m})$ transmission of the COVID-19 virus (SARS-CoV-2) in poorly ventilated spaces. These protocols should include up-to-date standards and selection/installation guidelines for the general public, businesses, and schools to facilitate adequate protection indoors.

\section{Acknowledgements}

The authors would like to acknowledge, with gratitude, the financial support provided through a grant from the MITACS (Mathematics of Information Technol- 
ogy and Complex Systems) E-Accelerate Program, through a MITACS/NSERC Alliance COVID-19 grant, and through a Mino-Bimaadiziwin/SSHRC Partnership Grant Fellowship.

\section{Conflicts of Interest}

The authors declare no conflicts of interest regarding the publication of this paper.

\section{References}

Abuhegazy, M., Talaat, K., Anderoglu, O., \& Poroseva, S. V. (2020). Numerical Investigation of Aerosol Transport in a Classroom with Relevance to COVID-19. Physics of Fluids, 32, Article ID: 103311. https://doi.org/10.1063/5.0029118

Alsved, M., Matamis, A., Bohlin, R., Richter, M., Bengtsson, P.-E., Fraenkel, C.-J. et al. (2020). Exhaled Respiratory Particles During Singing and Talking. Aerosol Science and Technology, 54, 1245-1248. https://doi.org/10.1080/02786826.2020.1812502

Aravindan, A., \& Lin, C. (2021). Vaccinated People Make up 75\% of Recent COVID-19 Cases in Singapore, but Few Fall Ill. Reuters, 23 July 2021.

https://www.reuters.com/world/asia-pacific/vaccinated-people-singapore-make-up-thr ee-quarters-recent-covid-19-cases-2021-07-23/

ASHRAE (2020, August). Reopening of Schools and Universities. https://www.ashrae.org/technical-resources/reopening-of-schools-and-universities

ASHRAE (2021, May 5). Epidemic Task Force: Schools \& Universities. https://www.ashrae.org/file\%20library/technical\%20resources/covid-19/ashrae-reopeni ng-schools-and-universities-c19-guidance.pdf

Aviation Public Health Initiative (2020). Assessment of Risks of SARS-CoV-2 Transmission during Air Travel and Non-Pharmaceutical Interventions to Reduce Risk. Harvard's Aviation Public Health Initiative.

Bahl, P., Doolan, C., de Silva, C., Chughtai, A. A., Bourouiba, L., \& MacIntyre, C. R. (2020). Airborne or Droplet Precautions for Health Workers Treating Coronavirus Disease 2019? The Journal of Infectious Diseases, jiaa189.

https://doi.org/10.1093/infdis/jiaa189

Barakat, T., Muylkens, B., \& Su, B.-L. (2020). Is Particulate Matter of Air Pollution a Vector of COVID-19 Pandemic? Matter, 3, 977-980.

https://doi.org/10.1016/j.matt.2020.09.014

Bernal, J. L., Andrews, N., Gower, C., Gallagher, E., Simmons, R., Thelwall, S., Stowe, J., Tessier, E., Groves, N., Dabrera, G., Myers, R., Campbell, C., Amirthalingam, G., Edmunds, M., Zambon, M., Brown, K., Hopkins, S., Chand, M., \& Ramsay, M. (2021). Effectiveness of COVID-19 Vaccines against the B.1.617.2 Variant. $B M$ J. https://doi.org/10.1101/2021.05.22.21257658

Bielecki, M., Patel, D., Hinkelbein, J., Komorowski, M., Kester, J., Ebrahim, S., Rodriguez-Morales, A. J., Memish, Z. A., \& Schlagenhauf, P. (2020). Air Travel and COVID-19 Prevention in the Pandemic and Peri-Pandemic Period: A Narrative Review. Travel Medicine and Infectious Disease, 39, Article ID: 101915.

https://www.sciencedirect.com/science/article/pii/S1477893920304117 https://doi.org/10.1016/j.tmaid.2020.101939

Boeing (2013). Air Change Rates in Planes, Trains and Buildings. Boeing. http://787updates.newairplane.com/Aviation-Experts 
Bourouiba, L. (2020). Turbulent Gas Clouds and Respiratory Pathogen Emissions: Potential Implications for Reducing Transmission of COVID-19. JAMA, 323, 1837-1838. https://doi.org/10.1001/jama.2020.4756

Brierley, C. (2020). Many Ventilation Systems May Increase Risk of COVID-19 Exposure, Study Suggests. EurekAlert!, 29 September 2020. https://www.eurekalert.org/pub releases/2020-09/uoc-mvs092920.php

Brown, C. M., Vostok, J., Johnson, H., Burns, M., Gharpure, R., Sami, S., Sabo, R. T., Hall, N., Foreman, A., Schubert, P. L., Gallagher, G. R., Fink, T., Madoff, L. C., Gabriel, S. B., MacInnis, B., Park, D. J., Siddle, K. J., Harik, V., Arvidson, D. et al. (2021). Outbreak of SARS-CoV-2 Infections, Including Covid-19 Vaccine Breakthrough Infections, Associated with Large Public Gatherings-Barnstable County, Massachusetts, July 2021. MMWR. Morbidity and Mortality Weekly Report, 70, 1059-1062. https://doi.org/10.15585/mmwr.mm7031e2

Bullister, E. (2021). System for Preventing Airborne Transmission of COVID-19 in Schools, Offices, and Similar Venues. Technical Disclosure Commons. https://www.tdcommons.org/dpubs series/4064/

Burgmann, S., \& Janoske, U. (2021). Transmission and Reduction of Aerosols in Classrooms Using Air Purifier Systems. Physics of Fluids, 33, Article ID: 033321. https://doi.org/10.1063/5.0044046

CBC (2021). B117 Coronavirus Variant Now Dominant Strain in Manitoba / CBC News. CBC, 30 April 2021.

https://www.cbc.ca/news/canada/manitoba/b117-variant-dominant-strain-in-manitoba $\underline{-1.6009292}$

Centers for Disease Control and Prevention (CDC) (2020a). Scientific Brief: SARS-CoV-2 and Potential Airborne Transmission. Centers for Disease Control and Prevention, 5 October 2020.

https://www.cdc.gov/coronavirus/2019-ncov/more/scientific-brief-SARS-CoV-2.html

Centers for Disease Control and Prevention (CDC) (2020b). Deciding to Go Out. Centers for Disease Control and Prevention, 30 October 2020.

https://stacks.cdc.gov/view/cdc/91350/cdc 91350

Centers for Disease Control and Prevention (CDC) (2020c). How Coronavirus Spreads. Centers for Disease Control and Prevention, 28 October 2020.

https://www.cdc.gov/coronavirus/2019-ncov/prevent-getting-sick/how-covid-spreads.h $\underline{\mathrm{tml}}$

Centers for Disease Control and Prevention (CDC) (2021). Interim Public Health Recommendations for Fully Vaccinated People. Centers for Disease Control and Prevention, 27 July 2021.

https://www.cdc.gov/coronavirus/2019-ncov/vaccines/fully-vaccinated-guidance.html

Christopherson, D. A., Yao, W. C., Lu, M., Vijayakumar, R., \& Sedaghat, A. R. (2020). High-Efficiency Particulate Air Filters in the Era of COVID-19: Function and Efficacy. Journal of the American Academy of Otolaryngology-Head and Neck Surgery Foundation, 163, 1153-1155. https://doi.org/10.1177/0194599820941838

CMTA (2020). Arlington Public Schools: Building Ventilation Assessment and Recommendations. 16 September 2020.

https://www.apsva.us/wp-content/uploads/2020/09/APS Ventilation Assessment 9-16 -2020.pdf

Comunian, S., Dongo, D., Milani, C., \& Palestini, P. (2020). Air Pollution and COVID-19: The Role of Particulate Matter in the Spread and Increase of COVID-19's Morbidity and Mortality. International Journal of Environmental Research and Public Health, 17, 
4487. https://doi.org/10.3390/ijerph17124487

Curtius, J., Granzin, M., \& Schrod, J. (2020). Testing Mobile Air Purifiers in a School Classroom: Reducing the Airborne Transmission Risk for SARS-CoV-2. Aerosol Science and Technology. https://doi.org/10.1101/2020.10.02.20205633

Curtius, J., Granzin, M., \& Schrod, J. (2021) Testing Mobile Air Purifiers in a School Classroom: Reducing the Airborne Transmission Risk for SARS-CoV-2. Aerosol Science and Technology, 55, 586-599. https://doi.org/10.1080/02786826.2021.1877257

D’Alessandro, V., Falone, M., Giammichele, L., \& Ricci, R. (2021). Eulerian-Lagrangian Modeling of Cough Droplets Irradiated by Ultraviolet-C Light in Relation to SARS-COV-2 Transmission. Physics of Fluids, 33, Article ID: 031905.

https://doi.org/10.1063/5.0039224

Deutsche Welle (DW) (2020). Coronavirus: Germany Unveils “Airing” Plan for Schools. DW.COM, 15 November 2020.

https://www.dw.com/en/coronavirus-germany-unveils-airing-plan-for-schools/a-55286 $\underline{311}$

Dolatabadi, A. M., Lakzian, E., Heydari, M., \& Khan, A. (2021). A Modified Model of the Suction Technique of Wetness Reducing in Wet Steam Flow Considering Power-Saving. Energy, 238, Article ID: 121685.

https://doi.org/10.1016/j.energy.2021.121685

Elfrink, T., Guarino, B., \& Mooney, C. (2020). CDC Reverses Itself and Says Guidelines It Posted on Coronavirus Airborne Transmission Were Wrong. The Washington Post, 29 September 2020.

https://www.washingtonpost.com/nation/2020/09/21/cdc-covid-aerosols-airborne-guid elines/

Environmental Protection Agency (2019). What Is a HEPA Filter? EPA, 3 April 2019. https://www.epa.gov/indoor-air-quality-iaq/what-hepa-filter-1

Environmental Protection Agency (2021a). Health and Environmental Effects of Particulate Matter (PM).

https://www.epa.gov/pm-pollution/health-and-environmental-effects-particulate-matt er-pm

Environmental Protection Agency (2021b). Frequent Questions about Wood-Burning Appliances. EPA, 30 March 2021.

https://www.epa.gov/burnwise/frequent-questions-about-wood-burning-appliances

Flanagan, R. (2020). Canada Follows WHO and U.S. in Acknowledging Aerosol Transmission of Coronavirus. CTV News, 5 November 2020.

https://www.ctvnews.ca/health/coronavirus/canada-follows-who-and-u-s-in-acknowle dging-aerosol-transmission-of-coronavirus-1.5176109

Fletcher, R., \& Olivier, A. (2021). Coronavirus: Quebec Recommends against Using Portable Air Purifiers in Schools. Global News, 10 January 2021.

https://globalnews.ca/news/7564002/coronavirus-quebec-air-purifiers-schools/

Foroozeh, F., Khoshnevis, A. B., \& Lakzian, E. (2020). Improvement of the Wet Steam Ejector Performance in a Refrigeration Cycle via Changing the Ejector Geometry by a Novel EEC (Entropy Generation, Entrainment Ratio, and Coefficient of Performance) Method. International Journal of Refrigeration, 110, 248-261.

https://doi.org/10.1016/j.ijrefrig.2019.11.006

Foster, A., \& Kinzel, M. (2021). Estimating Covid-19 Exposure in a Classroom Setting: A Comparison between Mathematical and Numerical Models. Physics of Fluids, 33, Article ID: 021904. https://doi.org/10.1063/5.0040755

Government of Canada (2015). Aboriginal Peoples: Fact Sheet for Canada. Statistics 
Canada, 30 November 2015.

https://www150.statcan.gc.ca/n1/pub/89-656-x/89-656-x2015001-eng.htm

Government of Canada (2021a). Coronavirus Disease (COVID-19): Locations Where You May Have Been Exposed to COVID-19. Canada.ca, 19 January 2021. https://open.canada.ca/data/en/dataset/8ee48eaf-408c-436f-a37e-4f74701d2447

Government of Canada (2021b). COVID-19: Improving Indoor Ventilation. Canada.ca, 14 January 2021.

https://www.canada.ca/en/public-health/services/diseases/2019-novel-coronavirus-infe ction/prevention-risks/covid-19-improving-indoor-ventilation.html

Government of Canada (2021c). COVID-19: Guidance on Indoor Ventilation during the Pandemic. 18 January 2021.

https://www.canada.ca/en/public-health/services/diseases/2019-novel-coronavirus-infe ction/guidance-documents/guide-indoor-ventilation-covid-19-pandemic.html\#a7

Government of Canada (2021d). Confirmed Cases of COVID-19. 14 September 2021. https://sac-isc.gc.ca/eng/1598625105013/1598625167707

Government of Quebec (2021). Guidelines Specific to Education (COVID-19). Gouvernement du Québec.

https://cdn-contenu.quebec.ca/cdn-contenu/adm/min/education/publications-adm/co vid-19/Feuillet rentree2021 AN.pdf?1628706740

Ham, S. (2020). Prevention of Exposure and Dispersion of COVID-19 Using Air Purifiers: Challenges and Concerns. Epidemiology and Health, 42, e2020027. https://doi.org/10.4178/epih.e2020027

Han, B., Kim, S.-B., Lee, G., Hong, G.-J., Park, I.-Y., Kim, H.-J., Lee, Y.-W., Kim, Y.-J., Jeong, S.-H., Shim, S.-H., Kim, J.-T., Roh, S.-A., Min, T.-J., \& Shin, W.-H. (2020). Analysis on Applicability of Air Purifiers in Schools to Prevent the Spread of Airborne Infection of SARS-CoV-2. Journal of Korean Society for Atmospheric Environment, 36, 832-840. https://doi.org/10.5572/KOSAE.2020.36.6.832

Harrison, R. M. (2020). Airborne Particulate Matter. Philosophical Transactions of the Royal Society A: Mathematical, Physical and Engineering Sciences, 378, Article ID: 20190319. https://doi.org/10.1098/rsta.2019.0319

Henriquez, G. (2020). Quebec Education Ministry Denies Forbidding Air Purifiers in French Public Schools. Global News, 9 December 2020.

https://globalnews.ca/news/7510130/quebec-education-ministry-air-purifiers-french-p ublic-schools/

Hoseinzade, D., Lakzian, E., \& Hashemian, A. (2021). A Blackbox Optimization of Volumetric Heating Rate for Reducing the Wetness of the Steam Flow through Turbine Blades. Energy, 220, Article ID: 119751. https://doi.org/10.1016/j.energy.2020.119751

Hosseini, R., \& Lakzian, E. (2020). Optimization Volumetric Heating in Condensing Steam Flow by a Novel Method. Journal of Thermal Analysis and Calorimetry, 140, 2421-2433. https://doi.org/10.1007/s10973-019-09001-1

Hung, I. F.-N., Cheng, V. C.-C., Li, X., Tam, A. R., Hung, D. L.-L., Chiu, K. H.-Y., Yip, C. C.-Y., Cai, J.-P., Ho, D. T.-Y., Wong, S.-C., Leung, S. S.-M., Chu, M.-Y., Tang, M. O.-Y., Chen, J. H.-K., Poon, R. W.-S., Fung, A. Y.-F., Zhang, R. R., Yan, E. Y.-W., Chen, L.-L. et al. (2020). SARS-CoV-2 Shedding and Seroconversion Among Passengers Quarantined after Disembarking a Cruise Ship: A Case Series. The Lancet Infectious Diseases, 20, 1051-1060. https://doi.org/10.1016/S1473-3099(20)30364-9

Jayaweera, M., Perera, H., Gunawardana, B., \& Manatunge, J. (2020). Transmission of COVID-19 Virus by Droplets and Aerosols: A Critical Review on the Unresolved Dichotomy. Environmental Research, 188, Article ID: 109819. 
https://doi.org/10.1016/j.envres.2020.109819

Jee, C. (2020). The CDC Has Finally Acknowledged That the Coronavirus Can Be Airborne. MIT Technology Review, 6 October 2020. https://www.technologyreview.com/2020/10/06/1009424/the-cdc-has-finally-acknowle dged-that-the-coronavirus-can-be-airborne/

Jones, N. R., Qureshi, Z. U., Temple, R. J., Larwood, J. P. J., Greenhalgh, T., \& Bourouiba, L. (2020). Two Metres or One: What Is the Evidence for Physical Distancing in COVID-19? BMJ, 370, m3223. https://doi.org/10.1136/bmj.m3223

Khanh, N. C., Thai, P. Q., Quach, H.-L., Thi, N.-A. H., Dinh, P. C., Duong, T. N. et al. (2020). Transmission of SARS-CoV 2 during Long-Haul Flight. Emerging Infectious Diseases, 26, 2617-2624. https://doi.org/10.3201/eid2611.203299

Kirkey, S. (2020). Possibility of “Airborne Transmission” of COVID-19 Can't Be Ruled Out, WHO Acknowledges. National Post, 7 July 2020.

https://nationalpost.com/news/airborne-transmission-of-covid-19-a-real-risk-239-scie ntists-tell-who

Kohanski, M. A., Lo, L. J., \& Waring, M. S. (2020). Review of Indoor Aerosol Generation, Transport, and Control in the Context of COVID- 19. International Forum of Allergy \& Rhinology, 10, 1173-1179. https://doi.org/10.1002/alr.22661

Li, H., Leong, F. Y., Xu, G., Kang, C. W., Lim, K. H., Tan, B. H., \& Loo, C. M. (2021). Airborne Dispersion of Droplets during Coughing: A Physical Model of Viral Transmission. Scientific Reports, 11, Article No. 4617.

https://doi.org/10.1038/s41598-021-84245-2

Li, Y., \& Qian, H. (2020). Evidence for Probable Aerosol Transmission of SARS-CoV-2 in a Poorly Ventilated Restaurant [WS01]. IAQ 2020 Conference, Seoul, 1-5 November 2020.

Lindsley, W. G., Derk, R. C., Coyle, J. P., Martin, S. B., Mead, K. R., Blachere, F. M., Beezhold, D. H., Brooks, J. T., Boots, T., \& Noti, J. D. (2021). Efficacy of Portable Air Cleaners and Masking for Reducing Indoor Exposure to Simulated Exhaled SARS-CoV-2 Aerosols-United States, 2021. MMWR. Morbidity and Mortality Weekly Report, 70, 972-976. https://doi.org/10.15585/mmwr.mm7027e1

Lurie, R., \& Ross, S. (2021). School Boards, Some Scientists Puzzled after Quebec Says Classroom Air Filters Don't Work. Montreal, 9 January 2021.

https://montreal.ctvnews.ca/school-boards-some-scientists-puzzled-after-quebec-saysclassroom-air-filters-don-t-work-1.5259702

Mahoney, J., \& Perreaux, L. (2020). Classrooms, Air Quality and COVID-19: What Steps Are Canadian School Boards Taking to Improve Ventilation? The Globe and Mail, 17 December 2020.

https://www.theglobeandmail.com/canada/article-classrooms-air-quality-and-covid-19 -what-steps-are-canadian-school/

Mariam, A. M., Joshi, M., Rajagopal, P. S., Khan, A., Rao, M. M., \& Sapra, B. K. (2021). CFD Simulation of the Airborne Transmission of COVID-19 Vectors Emitted During Respiratory Mechanisms: Revisiting the Concept of Safe Distance. ACS Omega, 6, 16876-16889. https://doi.org/10.1021/acsomega.1c01489

Mesgarpour, M., Abad, J. M., Alizadeh, R., Wongwises, S., Doranehgard, M. H., Ghaderi, S., \& Karimi, N. (2021). Prediction of the Spread of Corona-Virus Carrying Droplets in a Bus-A Computational Based Artificial Intelligence Approach. Journal of Hazardous Materials, 413, Article ID: 125358. https://doi.org/10.1016/j.jhazmat.2021.125358

Miller, A. (2020a). Canada Still Downplays Risk of Airborne Spread of Coronavirus Despite WHO, CDC Guidance. CBC News, 10 October 2020. 
https://www.cbc.ca/news/health/coronavirus-canada-airborne-spread-1.5758114

Miller, S. (2020b). Superspreading Events: How to Minimize Aerosol Transmission. [WS01]. IAQ 2020 Conference, Seoul, 1-5 November 2020.

Ministry of Health of Israel (2021). Ministry of Health of Israel. 1 August 2021. https://www.gov.il/BlobFolder/reports/vaccine-efficacy-safety-follow-up-committee/he /files publications corona two-dose-vaccination-data.pdf

Mirzaie, M., Lakzian, E., Khan, A., Warkiani, M. E., Mahian, O., \& Ahmadi, G. (2021). COVID-19 Spread in a Classroom Equipped with Partition-A CFD Approach. Journal of Hazardous Materials, 420, Article ID: 126587. https://doi.org/10.1016/j.jhazmat.2021.126587

Mittal, R., Meneveau, C., \& Wu, W. (2020). A Mathematical Framework for Estimating Risk of Airborne Transmission of COVID-19 with Application to Face Mask Use and Social Distancing. Physics of Fluids, 32, Article ID: 101903. https://doi.org/10.1063/5.0025476

Morawska, L. (2006). Droplet Fate in Indoor Environments, or Can We Prevent the Spread of Infection? Indoor Air, 16, 335-347. https://doi.org/10.1111/j.1600-0668.2006.00432.x

Morawska, L., \& Cao, J. (2020). Airborne Transmission of SARS-CoV-2: The World Should Face the Reality. Environment International, 139, Article ID: 105730. https://doi.org/10.1016/j.envint.2020.105730

Morawska, L., \& Milton, D. K. (2020). It Is Time to Address Airborne Transmission of Coronavirus Disease 2019 (COVID-19). Clinical Infectious Diseases, 71, 2311-2313. https://doi.org/10.1093/cid/ciaa939

Motamedi Zoka, H., Moshfeghi, M., Bordbar, H., Mirzaei, P. A., \& Sheikhnejad, Y. (2021). A CFD Approach for Risk Assessment Based on Airborne Pathogen Transmission. Atmosphere, 12, 986. https://doi.org/10.3390/atmos12080986

Mousavi, E. S., Godri Pollitt, K. J., Sherman, J., \& Martinello, R. A. (2020). Performance Analysis of Portable HEPA Filters and Temporary Plastic Anterooms on the Spread of Surrogate Coronavirus. Building and Environment, 183, Article ID: 107186. https://doi.org/10.1016/j.buildenv.2020.107186

Narayanan, S. R., \& Yang, S. (2021). Airborne Transmission of Virus-Laden Aerosols inside a Music Classroom: Effects of Portable Purifiers and Aerosol Injection Rates. Physics of Fluids, 33, Article ID: 033307. https://doi.org/10.1063/5.0042474

National Research Council (1999). Health Effects of Exposure to Radon: BEIR VI. The National Academies Press.

Noakes, C. J., \& Sleigh, P. A. (2008) Applying the Wells-Riley Equation to the Risk of Airborne Infection in Hospital Environments: The Importance of Stochastic and Proximity Effects. Indoor Air 2008: The 11th International Conference on Indoor Air Quality and Cl. Indoor Air 2008, Copenhagen, 17-22 August 2008, Denmark, 161-168.

Noakes, C. J., \& Sleigh, P. A. (2009). Mathematical Models for Assessing the Role of Airflow on the Risk of Airborne Infection in Hospital Wards. Journal of the Royal Society Interface, 6, S791-S800. https://doi.org/10.1098/rsif.2009.0305.focus

Nwanaji-Enwerem, J. C., Allen, J. G., \& Beamer, P. I. (2020). Another Invisible Enemy Indoors: COVID-19, Human Health, the Home, and United States Indoor Air Policy. Journal of Exposure Science \& Environmental Epidemiology, 30, 773-775. https://doi.org/10.1038/s41370-020-0247-x

Olsiewski, P. J., Bruns, R., Gronvall, G. K., Bahnfleth, W. P., Mattson, G., Potter, C., \& Vahey, R. A. (2021). School Ventilation: A Vital Tool to Reduce COVID-19 Spread. 
May 2021.

https://www.centerforhealthsecurity.org/our-work/pubs archive/pubs-pdfs/2021/2021 0526-school-ventilation.pdf

Ontario Labour Relations Board (2021). Expert Report of Dr. Jeffrey Siegel. https://www.aefo.on.ca/images/aefo/publications/autres/Expert Report Dr Jeffrey Sie gel.pdf

Pavilonis, B., Ierardi, A. M., Levine, L., Mirer, F., \& Kelvin, E. A. (2021). Estimating Aerosol Transmission Risk of SARS-CoV-2 in New York City Public Schools during Reopening. Environmental Research, 195, Article ID: 110805.

https://doi.org/10.1016/j.envres.2021.110805

Polyzois, P. (2019). Measuring the Concentration of Wood Stove Smoke Particulate Matter PM2.5 in a Single Room First Nations House. M.Sc. Thesis, Department of Biosystems Engineering, University of Manitoba.

Public Health Ontario (2020a). COVID-19 Routes of Transmission-What We Know So Far. 1 December 2020.

https://www.publichealthontario.ca/-/media/documents/ncov/covid-wwksf/2020/12/ro utes-transmission-covid-19.pdf?la $=$ en

Public Health Ontario (2020b). Use of Portable Air Cleaners and Transmission of COVID-19. Public Health Ontario: Frequently Asked Questions, 31 December 2020. https://www.publichealthontario.ca/-/media/documents/ncov/ipac/2021/01/faq-covid19-portable-air-cleaners.pdf?la=en

Ross, S. (2021). Quebec Schools without Air Purifiers Have 3 to 4 Times More COVID-19 Cases, Says Dad Running Citizen Count. Montreal, 24 April 2021.

https://montreal.ctvnews.ca/quebec-schools-without-air-purifiers-have-3-to-4-times-m ore-covid-19-cases-says-dad-running-citizen-count-1.5400739

Rosti, M. E., Olivieri, S., Cavaiola, M., Seminara, A., \& Mazzino, A. (2020). Fluid Dynamics of COVID-19 Airborne Infection Suggests Urgent Data for a Scientific Design of Social Distancing. Scientific Reports, 10, Article No. 22426. https://doi.org/10.1038/s41598-020-80078-7

Semmens, E. O., Noonan, C. W., Allen, R. W., Weiler, E. C., \& Ward, T. J. (2015). Indoor Particulate Matter in Rural, Wood Stove Heated Homes. Environmental Research, 138, 93-100. https://doi.org/10.1016/j.envres.2015.02.005

Setti, L., Passarini, F., De Gennaro, G., Barbieri, P., Perrone, M. G., Piazzalunga, A., Borelli, M., Palmisani, J., Di Gilio, A., Piscitelli, P., \& Miani, A. (2020). The Potential Role of Particulate Matter in the Spreading of COVID-19 in Northern Italy: First Evidence-Based Research Hypotheses. BMJ Open.

https://doi.org/10.1101/2020.04.11.20061713

Stephans, B. (2020). Mechanistic Transmission Modelling of COVID-19 on the Diamond Princess Cruise Ship Demonstrates the Importance of Aerosol Transmission [WS01]. IAQ 2020 Conference, Seoul, 1-5 November 2020.

Sze, S., Pan, D., Nevill, C. R., Gray, L. J., Martin, C. A., Nazareth, J. et al. (2020). Ethnicity and Clinical Outcomes in COVID-19: A Systematic Review and Meta-Analysis. EClinicalMedicine, 29, Article ID: 100630. https://doi.org/10.1016/j.eclinm.2020.100630

The Canadian Press (2021). Hundreds of Canadian Health Experts Call for Action on Airborne Spread of COVID-19. Global News, 4 January 2021.

https://globalnews.ca/news/7553766/coronavirus-aerosol-airborne-transmission/

Thompson, M. G., Burgess, J. L., Naleway, A. L., Tyner, H. L., Yoon, S. K., Meece, J., Olsho, L. E. W., Caban-Martinez, A. J., Fowlkes, A., Lutrick, K., Kuntz, J. L., Dunnigan, K., Odean, M. J., Hegmann, K. T., Stefanski, E., Edwards, L. J., Schaefer-Solle, N., 
Grant, L., Ellingson, K. et al. (2021). Interim Estimates of Vaccine Effectiveness of BNT162b2 and MRNA-1273 COVID-19 Vaccines in Preventing SARS-CoV-2 Infection among Health Care Personnel, First Responders, and Other Essential and Frontline Workers-Eight U.S. Locations, December 2020-March 2021. MMWR. Morbidity and Mortality Weekly Report, 70, 495-500. https://doi.org/10.15585/mmwr.mm7013e3

Thompson, S., Bonnycastle, M., \& Hill, S. (2020). COVID-19, First Nations and Poor Housing: "Wash Hands Frequently" and "Self-Isolate" Akin to "Let Them Eat Cake" in First Nations with Overcrowded Homes Lacking Piped Water. Canadian Centre for Policy Alternatives.

https://www.policyalternatives.ca/publications/commentary/fast-facts- $\% \mathrm{E} 2 \% 80 \% 9 \mathrm{Cwa}$ sh-hands-frequently\%E2\%80\%9D-and-\%E2\%80\%9Cself-isolate $\% \mathrm{E} 2 \% 80 \% 9 \mathrm{D}$-akin- $\% \mathrm{E}$ 2\%80\%9Clet-them-eat

Tran, P. T. M., Adam, M. G., \& Balasubramanian, R. (2021). Mitigation of Indoor Human Exposure to Airborne Particles of Outdoor Origin in an Urban Environment during Haze and Non-Haze Periods. Journal of Hazardous Materials, 403, Article ID: 123555. https://doi.org/10.1016/j.jhazmat.2020.123555

Tung, N. T., Cheng, P.-C., Chi, K.-H., Hsiao, T.-C., Jones, T., Bérubé, K. et al. (2021). Particulate Matter and SARS-Cov-2: A Possible Model of COVID-19 Transmission. Science of the Total Environment, 750, Article ID: 141532. https://doi.org/10.1016/j.scitotenv.2020.141532

van Doremalen, N., Bushmaker, T., Morris, D. H., Holbrook, M. G., Gamble, A., Williamson, B. N., Tamin, A., Harcourt, J. L., Thornburg, N. J., Gerber, S. I., Lloyd-Smith, J. O., de Wit, E., \& Munster, V. J. (2020). Aerosol and Surface Stability of SARS-CoV-2 as Compared with SARS-CoV-1. New England Journal of Medicine, 382, 1564-1567. https://doi.org/10.1056/NEJMc2004973

von Seidlein, L., Alabaster, G., Deen, J., \& Knudsen, J. (2021). Crowding Has Consequences: Prevention and Management of COVID-19 in Informal Urban Settlements. Building and Environment, 188, Article ID: 107472.

https://doi.org/10.1016/j.buildenv.2020.107472

World Health Organization (WHO) (2020a). Transmission of SARS-CoV-2: Implications for Infection Prevention Precautions. World Health Organization, 9 July 2020. https://www.who.int/news-room/commentaries/detail/transmission-of-SARS-CoV-2-i mplications-for-infection-prevention-precautions

World Health Organization (WHO) (2020b). Naming the Coronavirus Disease (COVID-19) and the Virus That Causes It. World Health Organization.

https://www.who.int/emergencies/diseases/novel-coronavirus-2019/technical-guidance Inaming-the-coronavirus-disease-(covid-2019)-and-the-virus-that-causes-it

Wu, X., Nethery, R. C., Sabath, M. B., Braun, D., \& Dominici, F. (2020). Air Pollution and COVID-19 Mortality in the United States: Strengths and Limitations of an Ecological Regression Analysis. Science Advances, 6, eabd4049.

https://projects.iq.harvard.edu/covid-pm/home https://doi.org/10.1126/sciadv.abd4049

Yazdani, S., \& Lakzian, E. (2020). Numerical Simulation and Passive Control of Condensing Flow through Turbine Blade by NVD Method Using the Eulerian-Lagrangian Model. Computers \& Mathematics with Applications, 80, 140-160. https://doi.org/10.1016/j.camwa.2020.03.007

Zhao, B., Liu, Y., \& Chen, C. (2020). Air Purifiers: A Supplementary Measure to Remove Airborne SARS-CoV-2. Building and Environment, 177, Article ID: 106918. https://doi.org/10.1016/j.buildenv.2020.106918 